農 村 の 生 活 構 造 と健康水準

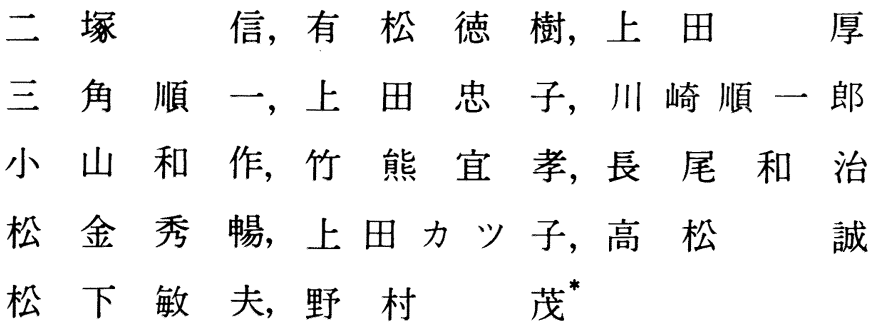

\section{1.はじめに}

ある集団について公衆衛生学的なアプローチを試み る場合，まず，その基礎資料として，諸種の統計資料 を利用し，あるいは集団健康診断の技法を用いて，そ の集団の集団としての特性を把握し，健康水準を把握 することが必要不可欠の要件である。特に，その集団 が機能的な結合によるものではない地域集団の場合， その重要性がより高まることはいうまでもない。

著者らは, 現在の我が国における疾病構造の様態を 考虑にいれたうえで，一定のスクリーニング技法を設 定し，そのスクリーニングレベルに従って，健康水準 を決定するための段階ずけを行ない, その地域的変動, 年令的変動, 性別変動, 季節的変動, 農作業様態によ る変動などを検討した。

こうした試みは，健康水準の概念とその内容を検討 することを通して，地域保健に対するアプローチの一 つにもなり得ると考える。

特に，従来比較的資料の乏しかった南九州農村にお ける農業従事者の健康水準を明らかにすることは，わ が国農村医学研究の地域的な課題の 1 つではないかと 思われる。

近年, 別に詳述するごとく, 農業生産構造の变動, 農村地域社会の地すべり的ともいえる変貌は必然的に 農村生活者, 農業従事者の健康に多様な影をおとして いる。かかる観点からも，地域保健を推進するうえで, 生産や生活の変動に伴う地域住民の健康水準の推移を 的確に把握し，これに速やかに対処することは, 近年 益々その重要性を増していると思われる。

\footnotetext{
*熊本農村医学研究会
}

受付：昭和48年 1 月 23 日

\section{2. 研 究 方 法}

\section{(1) 調査対象}

対象はすべて, 自らは健康だとして農作業および家 事作業に従事しており, 調査の時点で, 医治を受けて おらず, かつ, 就床もしくは休業をしていない 20 才か ら59 才までの既婚者である。

主な対象である農業従事者の場合, 1 農業協同組合 を 1 地域集団とみなして, 年令, 経営様態を考虑にい れた層別抽出によって，1農協より原則として 100 名 を対象とした。

農業従事者については, 昭和 42 年より 46 年までの 5 年間, 7 月中旬より 8 月中旬の夏季の農繁期直後 (一 部, 対照として 2 月), 図 1 に示すごとき地域を対象に

図1 調査対象地区分布図

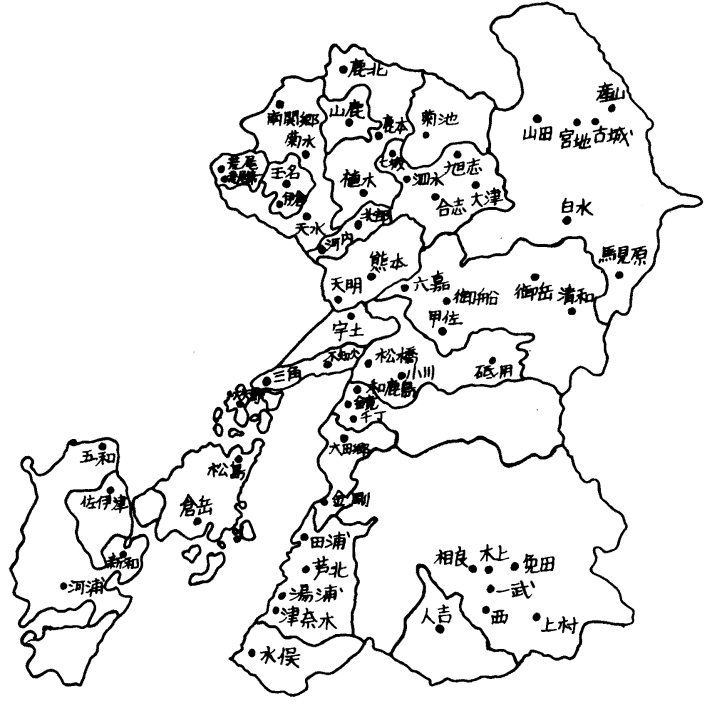


調査を行なった。調查対象は, 昭和 42 年 15 農協（夏 季 12 農協) 1,610 名, 43 年 13 農協 1,300 名（うち男子 100 名)，44 年 12 農協 1,200 名 (男子 100 名)，45 年 14 農協 1,396 名 (男子 635 名), 46 年 13 農協 1,091 名 (男子 492 名) で, 総計 67 農協 6,597名（うち男子 1,327 名)である。

調査对象の年令構成は図 2, 耕作面積別構成は図 3, 農家経営様態は表 1 に示すごとくである。これを熊本 県の農業従事者全体の構成区分からみると，本研究の 対象は, 専業農家（県平均 $26.1 \%$ ）に偏り，耕作面積

図 2 調查対象の年令構成

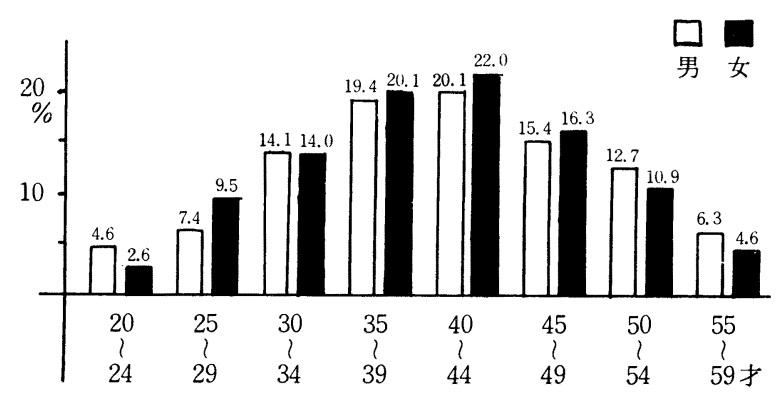

図 3 調査対象の耕作面積別構成

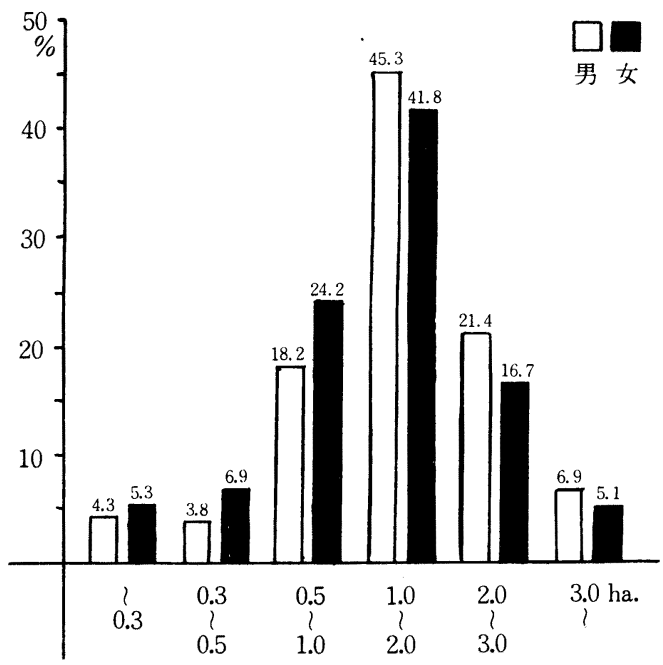

表 1 調査対象の専・兼別内訳け

$\begin{array}{lr}\text { 専 業 農 家 } & 4,299(74.5 \%) \\ \text { 第1 種兼業農家 } & 824(14.3 \%) \\ \text { 第 } 2 \text { 種兼業農家 } & 644(11.2 \%)\end{array}$

も $0.5 \mathrm{ha}$. 以下の層（県平均 $35.7 \%$ ）が相対的に少な く, 1.0ha. 以上の層（県平均 $38.2 \%$ ）に偏り，地域的 には山村部の対象が欠落した傾向にある。すなわち， 本研究の対象は, 熊本県における農政の重点施策対象 である゙自立経営・中堅農家層:ということができる。 なお，地域集団として対象の一部とした都市生活者 については，一小学校区を都市における地域集団とみ なして，校区婦人会より既述の方法によって対象を抽 出した。

\section{(2) 調査内容}

健康水準設定のための共通したスクリーニング項目 として，地域における慢性疾患あるいは慢性疲労を多 面的に把握するために，集団を対象とした多項目（多 相）スクリーニングの方式を採用し，同時に，調査当 日の健康指導が敏速に行なわれるように以下のごとき 項目を設定した。

(1) 体格, 体位, 体力測定

身長, 体重, 胸囲, 坐高, 上腕囲, 握力, 背筋力, 肺活量

(2) 農夫症に関する面接聞き取り調査

(3) 血液検査

血液型，血液比重（硫酸銅法）, 血色素量 (シアン メトへモグロビン法)

(4) 尿検 査

糖・蛋白定性検査 (テステープ法), ウロビリノー ゲン・ウロビリン定性検査 (スポット法), 沈渣 (鏡 検法）

(5) 屎 検 査

潜血反応 (グアヤク法)，虫卵検査（直接塗沫法お よび浮遊集卵法)

(6) 血圧測定, 心電図検査

(7) 一般診察

（3）健康水準の設定

上述の共通スクリーニング項目について，以下のご ときスクリーニングレベルを設定し，総合的な健康水 準を個人別に次の 5 段階に類別化した。

(1) 異常ありません。

(2) 僅かに異常を認めますが，日常生活には差し支 えありません。

（3）日常生活に注意し，保健婦・医師等の指導を受 けて下さい。

(4)（）の心配がありますので，今後様子をみ ていくか, もっと詳しい検査が必要です。

(5)治療を必要とします。(病名）

すなわち，以上のスクリーニングレベルにおいて， (1)・(2)の段階を一応, 健康者, (3)を異常者（不健康者 
ないしボーダーライン層), (4)(5)を有病者として把握 した。

調査内容におけるスクリーニングレベルの設定は以 下の要領によって行なった。

1）体格, 体位, 体力

生体計測值はBROCA の標準体重, 体力測定值は基 準值からの甚だしい逸脱を考虑して, やや不良，もし くは不良と判断されたものは(3)にスクリーニングした。

2)農夫症

日本農村医学会の様式に従い，士もしくは十を(3)に スクリーニングした。

\section{3）血液性状}

血液比重値 1.055 未満 (男子), 1.052 末満（女子）を (3)にスクリーニングした。血色素量 $13 \mathrm{~g} / \mathrm{d} \boldsymbol{l}$. 未満 (男 子), $12 \mathrm{~g} / \mathrm{d} \ell$. 未満 (女子) を(4)に, このうち, $12 \mathrm{~g} / \mathrm{d} \ell$. 未満 (男子), $11 \mathrm{~g} / \mathrm{d} \ell$. 未満 (女子) を(5)にスクリーニ ングした。

4）尿性 状

蛋白土, 糖士, ウロビリノーゲン十でかつビリルビ ンーは(2)に，蛋白十で沈渣にも異常所見の認められる 場合および糖十, ウロビリノーゲン＃は（4)にスクリー ニングした。

5）屎性状

潜血反応十は原則として (4)に, 人体有害寄生虫卵十 は(5)にスクリーニングした。

6) 血圧

収縮期血圧 $150 \mathrm{mmHg}$. 以上もしくは拡張期血圧 $90 \mathrm{mmHg}$. 以上は(4)に,このうち, 収縮期血圧 $160 \mathrm{mmHg}$. 以上も しくは拡張期血圧 $95 \mathrm{mmHg}$.は(5) にスクリーニングした。
なお, 収縮期血圧 $100 \mathrm{~mm} \mathrm{Hg}$. 未満については, 自党 症状を考虑して (2), (3)ないし (4)にスクリーニングし た。

7）心電図

日本循環器研究協議会判定基準案に従い, 血圧測定 值と理学的所見を考虑して (2)ないし(4)にスクリー二 ングした。

\section{8）一般診察}

既往歴, 家族歴, 生活歴を考虑して, 視診, 打診, 聴診, 触診における所見の有・無, その程度に応じて (2)，(3)，(4)，(5)にスクリーニングした。

以上のスクリーニングレベルはいずれも，普遍化し た集団検診スクリーニング基準に準拠したものである。 特に, 地域保健を推進する立場から, false-negative の度合を最小限度に, fal se-positive の度合を大にす るために，上に示した項目のうち，同一人で一項目に ついても健康水準区分の最も大きな数字を示したもの をそのまま, その個人の健康水準を示す段階として類 別化した。

\section{3. 研究 成}

農業従事者の健康水準を総括すると表 2 のごとくで ある。すなわち，婦人について，一応健康だといえる ものは, 昭和 42 年 $19.7 \%, 43$ 年 $14.6 \%, 44$ 年 9.0 $\%, 45$ 年 $17.9 \%, 46$ 年 $13.7 \%$ で，有病者（疑い）と みられるものは, 42 年 $43.4 \%, 43$ 年 $64.3 \%, 44$ 年 $70.6 \%, 45$ 年 $57.7 \%, 46$ 年 $57.0 \%$ である。また, 世 帯主について, 婦人と同規模の調査を行なった 45 年 以後の水準をみると, 健康者率は 45 年 $31.7 \%, 46$ 年

表 2 健 康 調查総合成 績

\begin{tabular}{|c|c|c|c|c|c|c|c|c|c|c|}
\hline & \multirow{2}{*}{ 判定 区 分 } & \multicolumn{2}{|c|}{ 平 均 值 } & \multirow{2}{*}{\begin{tabular}{|lr} 
昭r 和 \\
42 年度
\end{tabular}} & \multirow{2}{*}{\begin{tabular}{|l} 
昭 和 \\
43年度
\end{tabular}} & \multirow{2}{*}{\begin{tabular}{|l} 
昭 和 \\
44 年度
\end{tabular}} & \multicolumn{2}{|c|}{ 昭和 45 年度 } & \multicolumn{2}{|c|}{ 昭和46年度 } \\
\hline & & 男 & 女 & & & & 男 & 女 & 男 & 女 \\
\hline & 異常ありません & $\begin{array}{l}239 \text { 名 } \\
21.2 \%\end{array}$ & \begin{tabular}{|l}
624 \\
$(12.3)$
\end{tabular} & $\begin{array}{c}199 \\
(15.2)\end{array}$ & $\begin{array}{l}111 \\
(9.2)\end{array}$ & $\begin{array}{c}75 \\
(6.8)\end{array}$ & $\begin{array}{c}149 \\
(23.5)\end{array}$ & $\begin{array}{c}92 \\
(12.1)\end{array}$ & $\begin{array}{c}90 \\
(18.3)\end{array}$ & $\begin{array}{c}60 \\
(10.0)\end{array}$ \\
\hline (2) & $\begin{array}{l}\text { 僅かに異常を認めますが日常 } \\
\text { 生活には差し支えありません }\end{array}$ & $\begin{aligned} 80 \\
(7.1\end{aligned}$ & $\begin{array}{l}214 \\
(4.2)\end{array}$ & $\begin{array}{c}59 \\
(4.5)\end{array}$ & $\begin{array}{c}65 \\
(5.4)\end{array}$ & $\begin{array}{c}24 \\
(2.2)\end{array}$ & $\begin{array}{c}52 \\
(8.2)\end{array}$ & $\begin{array}{r}44 \\
(5.8)\end{array}$ & $\begin{array}{c}28 \\
(5.7)\end{array}$ & $\begin{array}{c}22 \\
(3.7)\end{array}$ \\
\hline (3) & 日常生活上注意が必要です & $\begin{array}{c}244 \\
(21.7)\end{array}$ & $\begin{array}{c}1325 \\
(26.2)\end{array}$ & $\begin{array}{c}484 \\
(36.9)\end{array}$ & $\begin{array}{c}254 \\
(21.4)\end{array}$ & $\begin{array}{c}225 \\
(20.5)\end{array}$ & $\begin{array}{c}111 \\
(17.5)\end{array}$ & $\begin{array}{c}186 \\
(24.4)\end{array}$ & $\begin{array}{c}133 \\
(27.0)\end{array}$ & $\begin{array}{l}176 \\
(29.4)\end{array}$ \\
\hline & 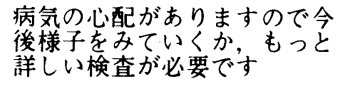 & $\begin{array}{r}343 \\
(30.4)\end{array}$ & $\begin{array}{c}1519 \\
(30.0)\end{array}$ & $\begin{array}{c}302 \\
(23.0)\end{array}$ & $\begin{array}{c}382 \\
(31.9)\end{array}$ & $\begin{array}{c}413 \\
(37.6)\end{array}$ & $\begin{array}{c}189 \\
(29.8)\end{array}$ & $\begin{array}{l}224 \\
(29.4)\end{array}$ & $\begin{array}{c}154 \\
(31.3)\end{array}$ & $\begin{array}{c}198 \\
(33.1)\end{array}$ \\
\hline (5) & 治療が必要です & $\begin{array}{l}221 \\
(19.6)\end{array}$ & $\begin{array}{l}1377 \\
(27.3)\end{array}$ & $\begin{array}{l}267 \\
(20.4)\end{array}$ & $\begin{array}{c}389 \\
(32.4)\end{array}$ & $\begin{array}{c}363 \\
(33.0)\end{array}$ & $\begin{array}{c}134 \\
(21.0)\end{array}$ & $\begin{array}{l}215 \\
(28.3)\end{array}$ & $\begin{array}{c}87 \\
(17.7)\end{array}$ & $\begin{array}{l}143 \\
(23.9)\end{array}$ \\
\hline & 総 & 1127 & 5059 & 1311 & 1201 & 1100 & 635 & $\begin{array}{lll}7 & 6 & 1\end{array}$ & $\begin{array}{lll}4 & 92\end{array}$ & $\begin{array}{lll}5 & 9 & 9\end{array}$ \\
\hline
\end{tabular}


表 3 熊本市街地域居住婦人の総合成績

\begin{tabular}{|c|c|c|}
\hline & 定 区 分 & 昭 和 46 年 \\
\hline (1) & 異常なし & $\begin{array}{c}32 \text { 名 } \\
(28.1 \%)\end{array}$ \\
\hline (2) & 大した異常なし & $\begin{array}{c}5 \\
(4.4)\end{array}$ \\
\hline (3) & 要 注 意 & $\begin{array}{c}23 \\
(20.2)\end{array}$ \\
\hline (4) & $\begin{array}{l}\text { 要精密㭘査 } \\
\text { 要経過観察 }\end{array}$ & $\begin{array}{c}36 \\
(31.6)\end{array}$ \\
\hline (5) & 要 治 療 & $\begin{array}{c}18 \\
(15.7) \\
\end{array}$ \\
\hline & 総 計 & 114 名 \\
\hline
\end{tabular}

$24.0 \%$, 有病者率は 45 年 $50.8 \%, 46$ 年 $49.0 \%$ であ る。

ちなみに, 熊本市の市街地域の家庭主婦の成績は表 3 のごとくで, 健康者率は $32.5 \%$, 有病者率は $47.4 \%$ と農家主婦との間に明瞭な格差を示しており, 特に (1) 異常なしの $28.1 \%$ が目立っている。

図4同一世帯の世帯主と主婦の健康水準

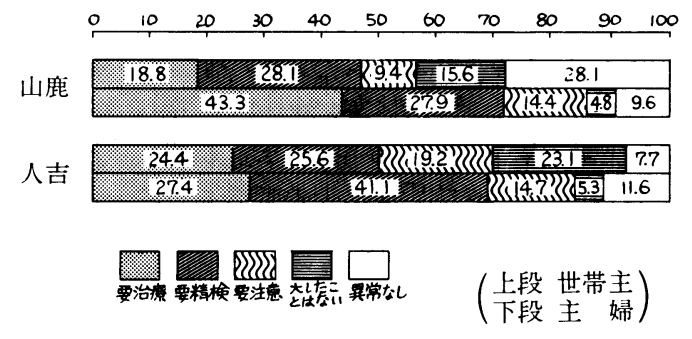

(1) 同一世帯の世帯主と主婦の健康水準

昭和 45 年 7 月に山鹿および人吉農協管内で実施した 同一世帯の世帯主，主婦各約 100 名の成績は図 4 のご とくである。両地域はともに図 7 のごとく，その健康 水準は熊本県下においても比較的低位にあるが，世帯 主と主婦との健康水準の格差は大きい。すなわち，山 鹿では, 世帯主で有病者率 $46.9 \%$, 健康者率 $43.7 \%$, 主婦で有病者率 $71.2 \%$ ，健康者率 $14.4 \%$ であった。 また，人吉では，それぞれ，世帯主で $50.0 \% ， 30.8 \%$ ， 主婦で $68.5 \%, 16.9 \%$ と, 両地域ともに両者に有意の 差を認める。なお，疾病構造は表 4 のごとくで，世帯 主の場所は高血圧に基因する心・血管疾患の比重が大 きく, 主婦では筫血症の比重が大きい。従って，その 内容は，当然のことながら，かなり異質のものであり， 季節的な推移も考虑にいれなければならない。

\section{（2）年令別にみた健康水準の推移}

年令別, 性別の健康水準の推移は図 5 のごとくであ る。加令による健康水準の低下傾向は男子に顕著であ る。すなわち, 男子では, 20 才代の有病者率は約 $45 \%$, 健康者率は約 $34 \%$ であるが，40 才以後では明瞭な健 康者率の減少と有病者率の増加が認められ, 殊に, 55 才以後では有病者率が $71 \%$, 健康者率が $8 \%$ で, 全て の対象者層のなかで最も健康水準が低位にある。他方, 女子では，すでに 20 才代より有病者率は $57 \%$, 健康 者率は $20 \%$ と低レベルにあり, 図 5 のごとく, 男子に みられる加令に伴う一元的な低下傾向はむしろ示さず, 30 才代前半で相対的に高位を示し，50才代後半ではや や回復の傾向を示しており，注目に值する所見である。 なお，年令階級別の疾病構造は図 6 のごとくで, 男子 では, 若年層の胃腸疾患, 高年層の循環器疾患, 女子 では, 若年層の唄血症, 高年層の循環器疾患が全体の 動向を規定している。

表 4 同一世帯の世帯主と主婦の疾病構造

\begin{tabular}{|c|c|c|c|c|c|c|c|c|c|c|}
\hline $\begin{array}{l}\text { 地 } \\
\text { 区 }\end{array}$ & $\begin{array}{l}\text { 性 } \\
\text { 別 }\end{array}$ & 貧 血 & 高血圧症 & 心 疾 患 & 胃腸障害 & 肝 疾 患 & $\begin{array}{l}\text { 堅 疾患 } \\
\text { 路 }\end{array}$ & 糖 尿病 & 奇生虫症 & その他 \\
\hline 山 & 世帯主 & $\begin{array}{c}16 \text { 件 } \\
(23.2 \%)\end{array}$ & $\begin{array}{c}16 \\
(23.2)\end{array}$ & $\begin{array}{c}11 \\
(15.9)\end{array}$ & $\begin{array}{c}15 \\
(21.7)\end{array}$ & $\begin{array}{c}1 \\
(1.5)\end{array}$ & 0 & $\begin{array}{c}2 \\
(2.9)\end{array}$ & $\begin{array}{c}8 \\
(11.6)\end{array}$ & 0 \\
\hline 鹿 & 主 婦 & $\begin{array}{c}65 \\
(68.4)\end{array}$ & $\begin{array}{c}9 \\
(9.5)\end{array}$ & $\begin{array}{c}4 \\
(4.2)\end{array}$ & $\begin{array}{c}6 \\
(6.3)\end{array}$ & $\begin{array}{c}2 \\
(2.1)\end{array}$ & $\begin{array}{c}1 \\
(1.1)\end{array}$ & 0 & $\begin{array}{c}8 \\
(8.4)\end{array}$ & 0 \\
\hline 人 & 世帯主 & $\begin{array}{c}8 \\
(17.0)\end{array}$ & $\begin{array}{c}25 \\
(53.2)\end{array}$ & $\begin{array}{c}3 \\
(6.4)\end{array}$ & $\begin{array}{c}3 \\
(6.4)\end{array}$ & $\begin{array}{c}1 \\
(2.1)\end{array}$ & $\begin{array}{c}1 \\
(2: 1)\end{array}$ & $\begin{array}{c}1 \\
(2.1)\end{array}$ & $\begin{array}{c}4 \\
(8.5)\end{array}$ & $\begin{array}{c}1 \\
(2.1)\end{array}$ \\
\hline 吉 & 主 婦 & $\begin{array}{c}45 \\
(48.4)\end{array}$ & $\begin{array}{c}19 \\
(20.4)\end{array}$ & $\begin{array}{c}8 \\
(8.6)\end{array}$ & $\begin{array}{c}6 \\
(6.5)\end{array}$ & $\begin{array}{c}5 \\
(5.4)\end{array}$ & $\begin{array}{c}1 \\
(1.1)\end{array}$ & 0 & $\begin{array}{c}7 \\
(7.5)\end{array}$ & $\begin{array}{c}2 \\
(2.2)\end{array}$ \\
\hline
\end{tabular}


図 5 性別・年令別にみた健康水準
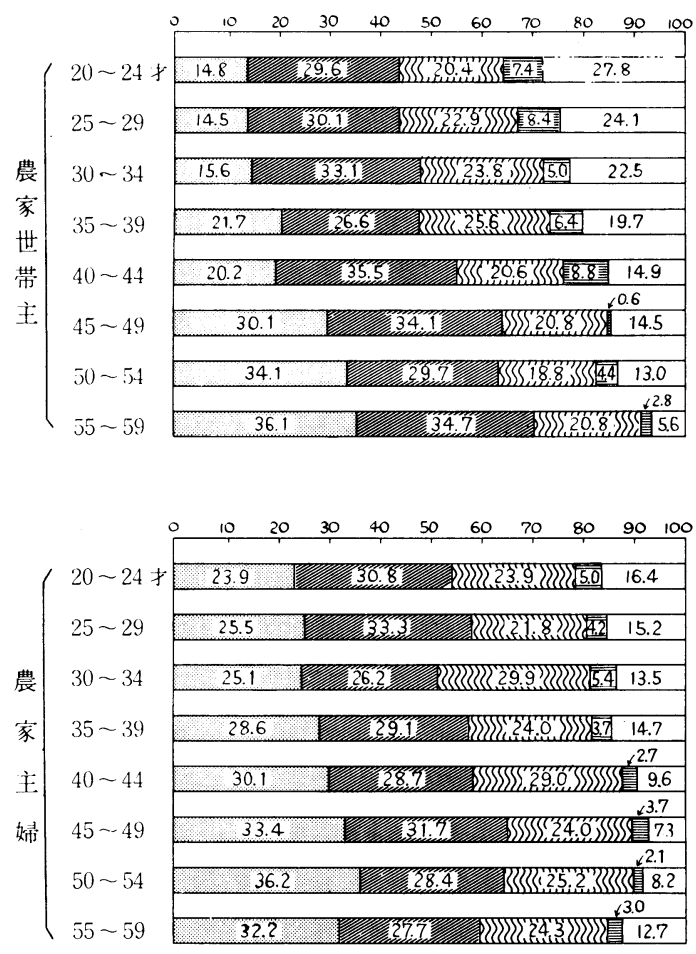

\section{（3）季節別にみた健康水準の推移}

昭和 43 年 8 月および 44 年 2 月に, 同一対象につい て同様の方法で調查した千丁農協における女子の成績 は図 7 のごとくである。

ちなみに, 当該地域は熊本県下で屈指の藺業地帯で, 8 月は 6 月以来続いた鹳草収穫と田植え作業の疲労が 累積した時期であり，2月は一部の施設園芸農家を除 いては, 主な農作業は畳表製織作業程度で, 農繁・閉 期の労働負担の違いが最も顕著な地域である。

図 7 のごとく, 8 月には, 有病者率 $62.0 \%$, 健康者 率 $9.0 \%$ であるのに対して，2 月には，それぞれ，
図 6 主要疾患の性別・年令別有病率
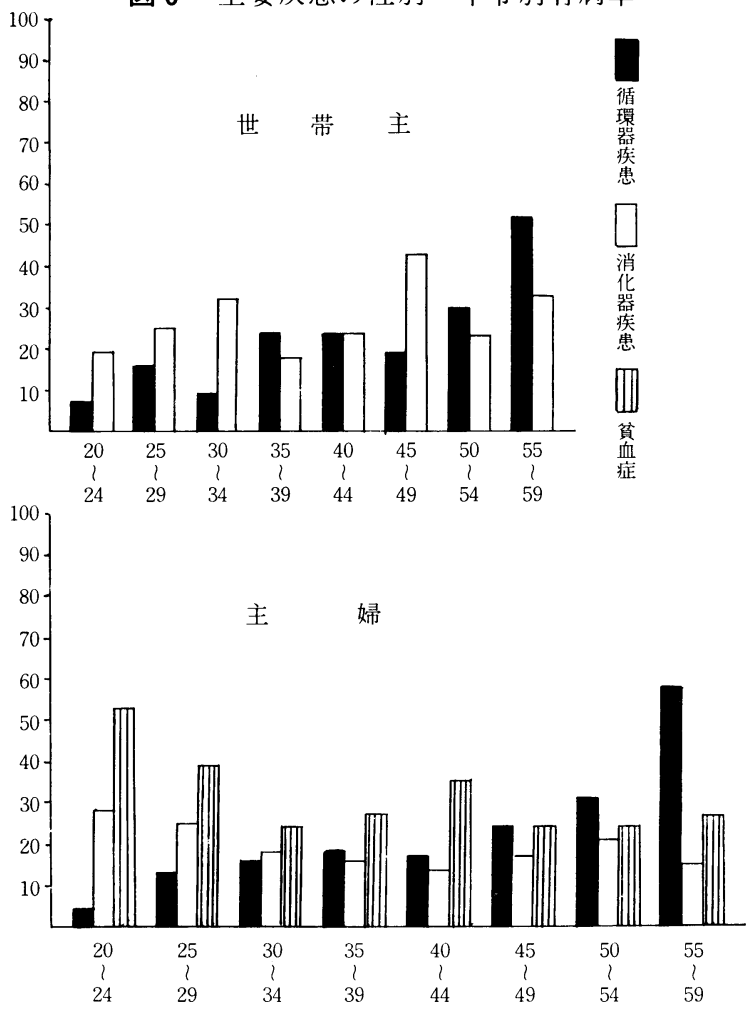

図 7 農家主婦の季節別にみた健康水準の推移

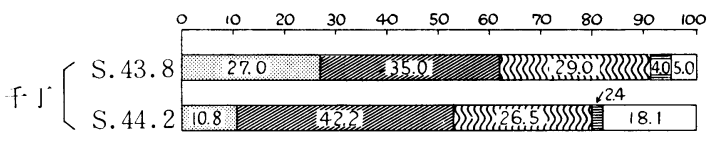

$53.0 \%, 20.5 \%$ と有意の変動を示している。この間， 特に，(5)の段階にあるものの減少と，(1)の段階にある ものの増加がなかでも顕著である。農繁・閑期の疾病 構造の推移は表 5 のごとくである。すなわち， 2 月は 8 月に比し, 貿血症, 高血圧症, 寄生虫症の減少がみ

表 5 季節別にみた疾病構造（農家主婦）

\begin{tabular}{|c|c|c|c|c|c|c|c|c|c|c|}
\hline & & 筫 血 & 高血圧症 & 心疾 患 & 胃腸障害 & 肝疾 患 & $\begin{array}{l}\text { 腎 } \\
\text { 尿路 }\end{array}$ & 糖 尿 病 & 奇生虫症 & その 他 \\
\hline 8 & 月 & $\begin{array}{c}32 \text { 件 } \\
(34.8 \%)\end{array}$ & $\begin{array}{c}17 \\
(18.5)\end{array}$ & $\begin{array}{c}3 \\
(3.3)\end{array}$ & $\begin{array}{c}23 \\
(25.0)\end{array}$ & $\begin{array}{c}8 \\
(8.7)\end{array}$ & $\begin{array}{c}1 \\
(1.1)\end{array}$ & $\begin{array}{c}1 \\
(1.1)\end{array}$ & $\begin{array}{c}7 \\
(7.6)\end{array}$ & 0 \\
\hline 2 & 月 & $\begin{array}{c}19 \\
(31.2)\end{array}$ & $\begin{array}{c}10 \\
(16.4)\end{array}$ & $\begin{array}{c}6 \\
(7.2)\end{array}$ & $\begin{array}{c}19 \\
(31.1)\end{array}$ & $\begin{array}{c}3 \\
(4.9)\end{array}$ & $\begin{array}{c}2 \\
(3.3)\end{array}$ & $\begin{array}{c}1 \\
(1.6)\end{array}$ & $\begin{array}{c}1 \\
(1.6)\end{array}$ & 0 \\
\hline
\end{tabular}


られ，胃腸障害には差異がなく，少数ながら心疾患（疑 い）の有病者率が増加をみている。

また，男子の季節的な推移は，昭和 45 年 7 月および 46 年 2 月に同様の方法で調査した人吉農協の成績によ つて検討した。

当該地域は, 典型的な山付きの平場水田, 畑作地帯 の一つで, 水稲, 麦作, 煙草, 酪農, 畜産で経営を構 成しており，従って，千丁に比すれば農繁・閑期の労 働負担の差異は顕著でない。しかし，近年，農閑期に おける農外賃労働の比重が次第に高まりつつあること にも注目しなければならない。

成績は図 8 のごとくで, 千丁のごとく農繁・閑期の

図 8 季節別にみた健康水準（農家世帯主）

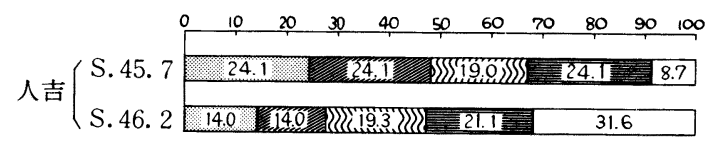

労働負担の差異は顕著でないにもかかわらず，有病者 率は $48.2 \%$ から $28.0 \%$, 健康者率は $32.8 \%$ から $52.7 \%$ へと, 冬季の著明な水準の向上がみられる。疾 病構造の季節的推移は表 6 のごとくで, 2 月には, 貧
血症, 寄生虫症の減少と心疾患の増加が目立っている。 当該地域は, 元来, 高血圧症罹患率の高い地域である が，この傾向はすでに夏季にも顕著である。いずれに しても，このように疾病構造の相違にもかかわらず, 冬季の水準上昇の傾向が男子にむしろ強いことは注目 すべき現象である。

(4) 地域別にみた健康水準の分布

夏季に健康調査を行なった農家主婦 62 地域，世帯主 25 地域 (昭和 45 年以後) の健康水準の地域的な分布は 図 $9 ， 10,11,12$ のごとくである。すなわち，農家主 婦について，特に有病者率の高い地域は山鹿 $(95.0 \%)$ を始め, 新和 $(81.2 \%)$, 木上 $(81.1 \%)$, 上村 $(81.0$ $\%)$ ，松橋 $(79.0 \%)$ などで，いずれも，筫血症や寄生 虫症の罹患が目立っている。逆に, 有病者率の低い地 域は大津 $(30.0 \%)$ を始め, 七城 $(37.0 \%)$, 菊水 $(37.6$ $\%)$, 天明 $(38.1 \%)$ などである。図 13 のごとく,地 域的に, 必ずしも有病者率と健康者率とは逆相関関係 を示さないところもある。

健康者率の高い地域は北部 $(36.0 \%)$ を始めとして, 大津 $(34.0 \%)$, 植木 $(32.6 \%)$, 七城 $(31.0 \%)$ など で, 低い地域は山鹿 $(1.0 \%)$ を始め, 海東 $(3.3 \%)$, 倉岳 $(3.8 \%)$, 新和 $(4.0 \%)$, 田浦 $(4.0 \%)$, 馬見原 $(4.0 \%)$, 荒尾（南部） $(4.0 \%)$ などである。

表 6 季節別にみた疾病構 造（農家世帯主）

\begin{tabular}{|c|c|c|c|c|c|c|c|c|c|}
\hline & 筫 血 & 高血圧症 & 心 疾 患 & 胃腸障害 & 肝疾 患 & $\begin{array}{c}\text { 腎 } \\
\text { 尿路 } \\
\text { 疾患 }\end{array}$ & 糖尿病 & 奇生虫症 & その他 \\
\hline 7 月 & $\begin{array}{c}8 \text { 件 } \\
(17.0 \%)\end{array}$ & $\begin{array}{c}25 \\
(53.2)\end{array}$ & $\begin{array}{c}3 \\
(6.4)\end{array}$ & $\begin{array}{c}3 \\
(6.4)\end{array}$ & $\begin{array}{c}1 \\
(2.1)\end{array}$ & $\begin{array}{c}1 \\
(2.1)\end{array}$ & $\begin{array}{c}1 \\
(2.1)\end{array}$ & $\begin{array}{c}4 \\
(8.5)\end{array}$ & $\begin{array}{c}1 \\
(2.1)\end{array}$ \\
\hline 2 月 & $\begin{array}{c}2 \\
(10.0)\end{array}$ & $\begin{array}{c}11 \\
(55.0)\end{array}$ & $\begin{array}{c}6 \\
(30.0)\end{array}$ & 0 & 0 & 0 & $\begin{array}{c}1 \\
(5.0)\end{array}$ & 0 & 0 \\
\hline
\end{tabular}

また，世帯主についてみると，有病者率の高い地域 は海東 $(76.9 \%)$ を始め, 木上 $(72.3 \%)$, 植木 $(58.3$ $\%)$ などで, 有病者率の低い地域は小川 $(18.2 \%)$, 小 野部田 $(25.0 \%)$, 津奈木 $(34.7 \%)$ などである。また, 健康者率の高い地域は, 津奈木 $(53.1 \%)$, 小野部田 $(50.0 \%)$, 小川 $(45.4 \%)$ などで, 健康者率の低い地 域は木上 $(6.4 \%)$, 相良 $(9.1 \%)$, 荒尾（南部） (18.0 \%) などである。

健康水準の地域的な分布を概観すれば，図 11 のごと く, 農家主婦では, 熊本市近郊から菊池, 玉名にかけ ての米作, 近郊農村地帯が高く, 県北の鹿本地方の一
部および八代の藺業地帯, 天草, 球磨地方が低い。世 帯主については, 図12のごとく, 県南の果樹園地帯に 高く, 球磨および八代の藺業地帯の一部に低い。

なお, このような地域的な健康水準の相違は, 地域 を構成する多様な要因が相互に関連し合いながら, 一 つの Indicator として総合化されて導き出された結果 であることはいうまでもない。このような地域差のよ つてきたる要因については考察で詳しく触れる。

(5) 農業経営様態別にみた健康水準

全ての調査対象について農業経営の様態の相違によ る健康水準の差異を検討した。 
図9農家主:婦の地域別水準

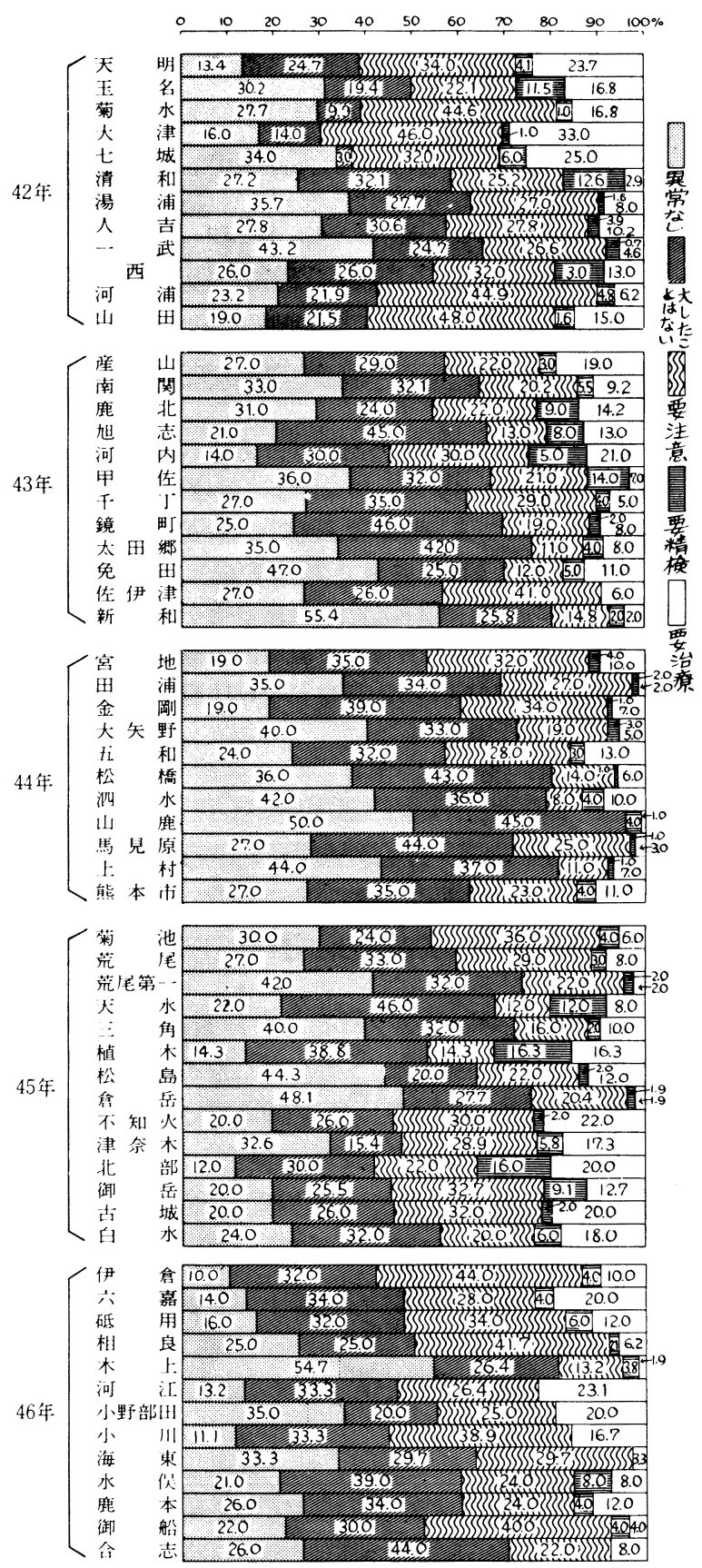

専 ・兼別の健康水準は四 14 のごとくである。専・兼 別の相違は主婦よりもむしろ世带主に顕著で, 二種兼 業では他に比し有病者率が有意に高く, 異常なしとさ れるものの割合が有意に低い。

経営面積別の健康水準は困 15 のごとくで, 主婦, 世
図10 農家世帯主の地域別水準
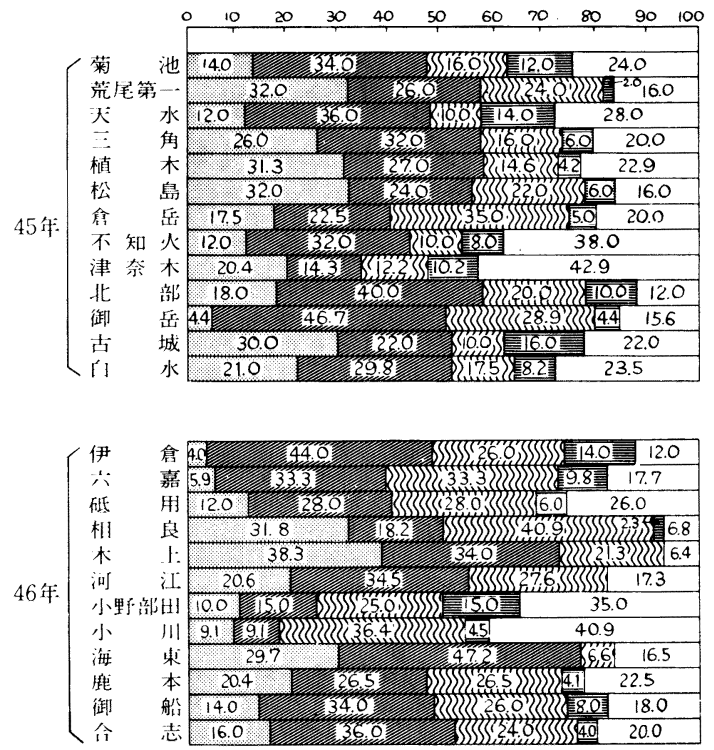

図11 農家主婦の健康者率

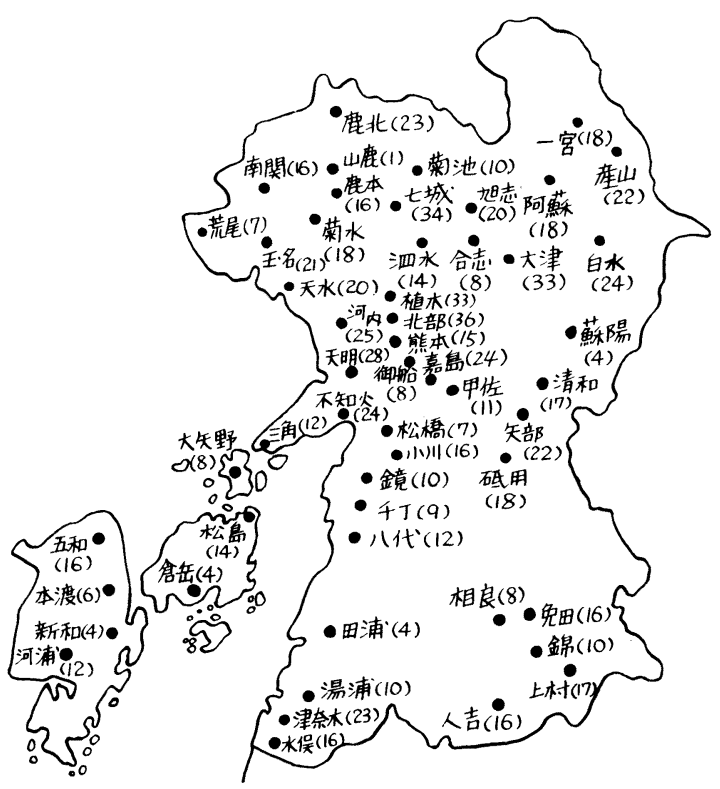

帯主ともに0.3ha. 未満の層に比較的顕著な水準の低下 がみられる。この層は, 上述の二種兼業農家の層と相 重なった層といえる。他方, 主婦, 世帯主ともに, 経 営面積が大規模になるに伴って，水準の上昇をみるが, 特にこの傾向は世帯主に顕著で，0.3ha. 未満の層と 0.3 ha. 以上の層とでは, 有病者率で約 $10 \%$, 健康者率で 約 $15 \%$ の相違がみられる。 
图12農家世帯主の健康者率

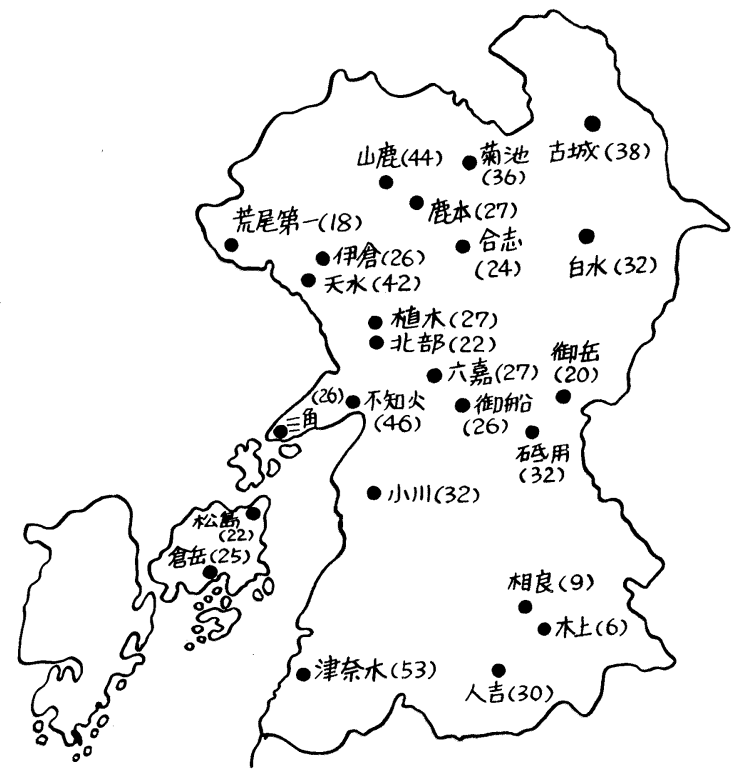

図14 専・兼別にみた健康水準
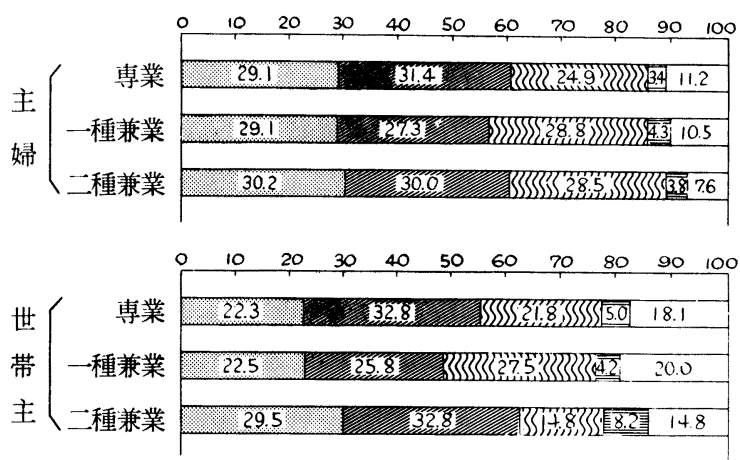

本人，または配偶者の出稼ぎ，あるいは通いの農外 労働（賃仕事など）の有・無による健康水準の相違は, 図 16 のごとくである。すなわち, 出稼ぎに出ている層 の水準が高く, 有病者率では $43.2 \%$ と $55.9 \%$, 健康 者率では $24.5 \%$ と $17.2 \%$ と有意の差が認められる。 熊本県の場合, 農外労働の比重は, 出稼ぎ (県外) よ りもむしろ通いの土木工事などの賃仕事が高いが，こ

図13 地域別の健康水準分布図

農 家主婦

$\mathrm{N}=62$

$\mathrm{r}=-0.69$

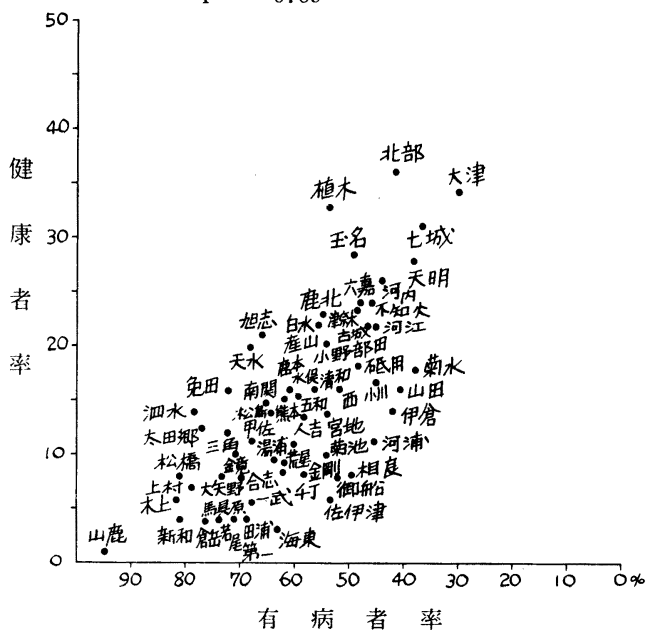

の型で農外労働に依存している層は出稼ぎとは逆に水 準が低く, 有病者率では $64.6 \%$ と $55.5 \%$, 健康者率 では $11.7 \%$ と $17.6 \%$ と有意の差が認められる。これ は, また，上述の二種兼業あるいは $0.3 \mathrm{ha}$. 未満の層の

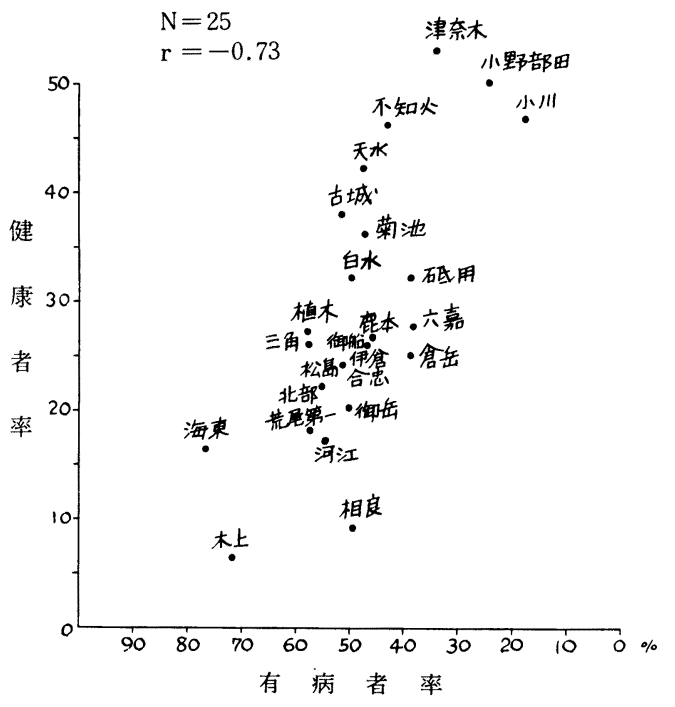

低水準と軌を一にするものである。

最近の農家の労働負担の程度は, 水稲と組合せて行 なわれる各種の複合経営の様態によって質・量ともに 規定されていると思われる。複合経営の内容を農業だ 
図15 経営面積別にみた健康水準
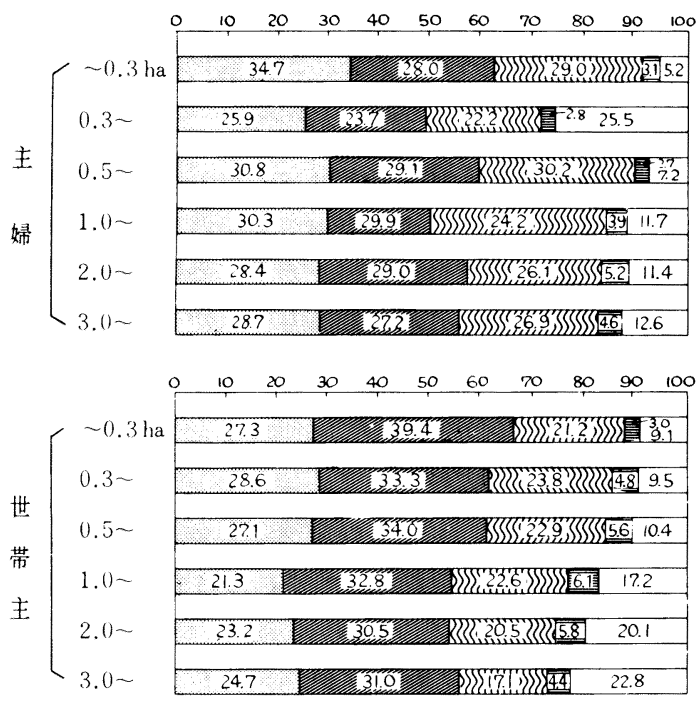

図16農外労働の面からみた健康水準

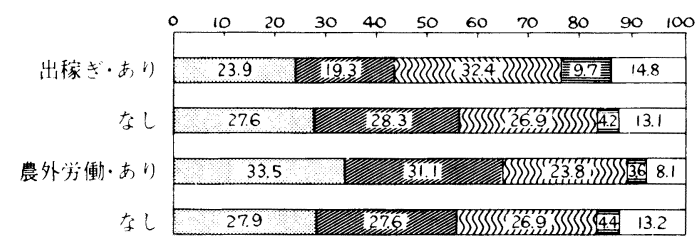

図17複合経営の内容からみた健康水準
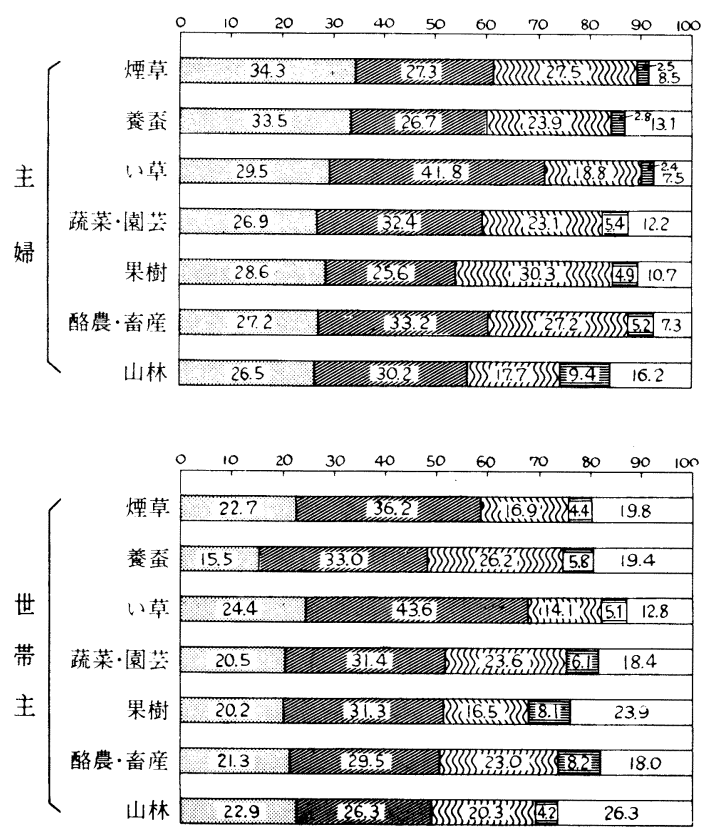

けに限定した場合, これと健康水準との関連は図 17 の ごとくである。すなわち，世帯主，主婦ともに共通し て相対的に高い水準にあるのは, 果樹農家であり, 低 い水準にあるのは蔡業農家である。本県の農業生産性 の伸びを支えるこの二品目が，こうした対照を示すの は興味深いが, 両者の農業労働負担の程度を考虑すれ ば首肯されるところである。この他では，山林農家は 比較的高水準，煙草耕作農家は比較的低水準を示した。 また, 複合経営の様態と健康水準との関連をみるとき, 世帯主と主婦とが強い相関性を示し, 同様の傾向を示 しており，注目されるところである。

(6) 健康水準と疾病構造

すでに触れたごとく，スクリーニングされた疾病や 異常は多様で, 表面上は同じ有病者, 異常者として取 り扱われても，その内容は種々の要因によって大きな 差異がみられる。

全ての対象について, 性別, 疾患別の有病率を図 18 に，疾病構造を図19に示した。すなわち，男子では高

図18 性別・疾患別有病率

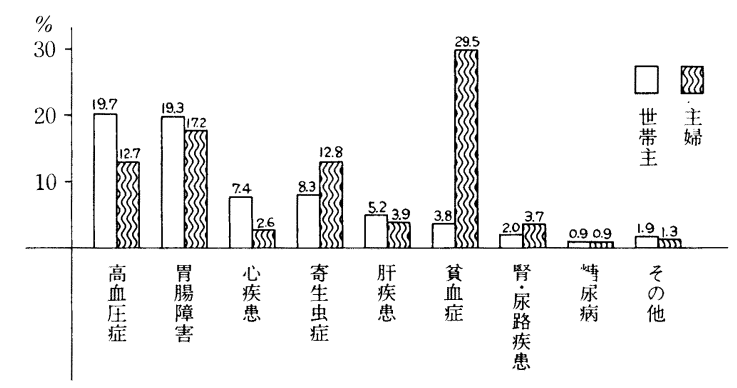

図19性別にみる疾病構造

\begin{tabular}{|c|c|c|c|c|}
\hline 胃腸障害 28.3 & $\mid \begin{array}{c}\text { 旰矤慗 } \\
7.7\end{array}$ & $\begin{array}{c}\text { 奇生蝊 } \\
12.1\end{array}$ & 高血王症 28.8 & 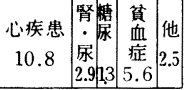 \\
\hline
\end{tabular}

(主

婦)

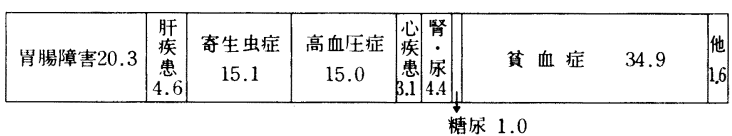

血圧症の $19.7 \%$ を始め, 心疾患, 腎疾患, 糖尿病のご とき循環器系の異常と直接的な関連のある成人病の有 病率が $30.0 \%$ で, 発見された全疾病のうちの $43.8 \%$ を占める。次いで, 胃腸障害の $19.3 \%$ を始め, 消化器 疾患の有病率は $24.5 \%$ で, 全疾病の $36.0 \%$ を占め, 督血症は僅かに $5.6 \%$ に過ぎない。他方，女子では， 筫血症の有病率が $29.5 \%$ と最も高く, 全疾病のうちの 
$34.9 \%$ を占める。次いで, 消化器系疾患の有病率が $21.1 \%$ で，全疾病の $25.3 \%$ である。男子に最も高い 頻度でみられた循環器系疾患の有病率は $19.9 \%$ で, 全 疾病の $23.5 \%$ である。なお, 奇生虫症も, 有病率は男 子で $8.3 \%$, 女子で $12.8 \%$ と軽視し難い実情にあるこ とを示している。

これら対象者の疾病構造のなかで大きなウエイトを 占める循環器疾患, 消化器疾患, 筫血症の年令階級別 の有病率はすでに図 5 に示したごとくである。

ちなみに, 表 3 のごとき, 市街地域の家庭主婦の疾 患別有病率および疾病構造は図 20,21 のごとくである。

図20 疾患別有 病率（都市家庭主婦）

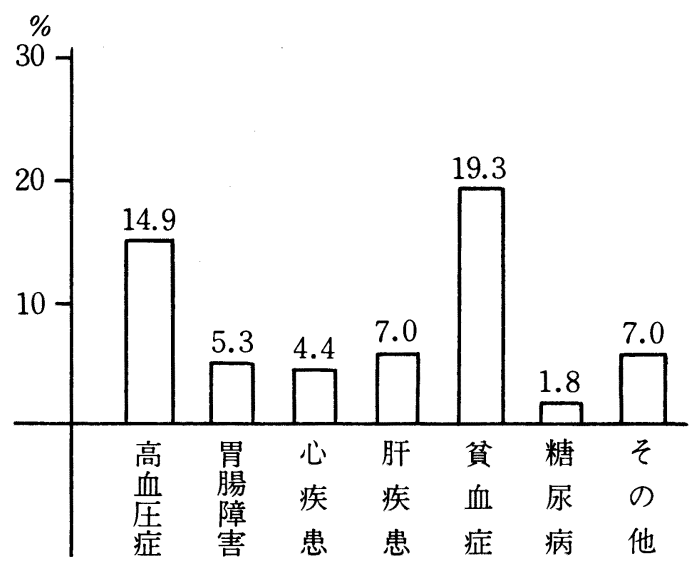

図21 疾 病 構 造 (都市家庭主婦)

\begin{tabular}{|c|c|c|c|c|c|c|c|}
\hline 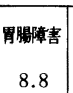 & $\begin{array}{c}\text { 肝疾患 } \\
11.8\end{array}$ & 高血王症 25.0 & $\begin{array}{l}\text { 心属患 } \\
7.4\end{array}$ & \begin{tabular}{|c|} 
精 \\
水 \\
2.9
\end{tabular} & 英血症 & 32.4 & $\begin{array}{c}\text { その他 } \\
11.8\end{array}$ \\
\hline
\end{tabular}

すなわち, 筫血症の有病率が $19.3 \%$ と最も高く, 全疾 病のうちの $32.4 \%$ を占める。また, 循環器系疾患も筫 血症と全く同様の有病率 $19.3 \%$ を示しており, 次いで, 肝疾患 (疑い) $97.0 \%$, 消化器疾患 (胃腸障害) の $5.3 \%$ などであり，その疾病構造は農家主婦の場合と は明らかに異なった様相を呈している。

\section{3}

ある集団について，その健康水準を論じる場合，そ の集団の大きさと質, 均一性, 健康水準測定のための 指標に何を選ぶかがまず問題になる。

著者らは，その集団の大きさを一農業協同組合単位 の地域にとった。農協所管の地域は, 現在, 合併され た町村の規模をそのまま持っている部分と合併前町村
の規模を保っている部分が複雑に入り乱れているが, いわゆる，第一次集団としての地域を把握し，小地域 集団としての健康水準を測定するためには，少なくと も現在の時点においては, 行政単位よりは濃厚な地域 的属性を持っていると考えられる。

次に，集団の質の基本的な共通基盤として，農業協 同組合の正組合員たる農業従事者を原則として選択し た。勿論, 現在の社会構造のなかで, 農協組合員であ ることが地域集団の共通基盤たり得るかどうかは議論 のあるところで, 本研究のなかでも若干の分析を試み た。

さて, 地域集団の健康水準測定の指標としては, 諸 種の資料が提示され，利用されているが，著者らは小 地域集団におけるいわゆる健康者を対象とした多項目 スクリーニングの成績をもってこれに当てた。ただし， 多項目スクリーニングの内容は, 現今, いわゆる A. M. H. T を始めとする集団検診技術の新たな展開の下 で, より複雑化，多様化しようとしているのであるが, 本研究の場合, 寸でに触れたごとく, 第一次スクリー ニングの段階におけるチェックであり, 基本的な項目 の一つと考えられる消化器系の理学的検討項目が欠け ていることをつけ加えておかなければならない。しか しながら, 単一のチェック項目による健康水準設定の 試みに比すれば，いくつかの基本的なチェックの組合 せにより,いくらかは総合性を帯びたものとして評価 され得るのではないかと考える。とくに, 健康者の位 置づけについては諸説のあるところであるが, 重松ら が紹介した Bexley 地区における健康者の疫学調査の 考え方に近いといってよいであろう。

著者らが集団の健康水準を表現するために用いた術 語の概念規定について明確にしておく必要がある。

すなわち, 図 22 に模式化したごとく, 諸検査所見に 何らの異常も認められない群を Better Health(healthy) としてまとめ, 無所見者, すなわち健康者とした。次 に, 自党的, 他党的に何らかの異常を認めた群を III Health, 非 (不) 健康者, すなわち有所見者と総括し, その程度に応じて, 有症者 (異常者), 有病者, 病者 に区分した。そして, 特定, 単一の項目について陽性 所見の出現頻度や一定のスクリーニングレベルから逸 脱した異常值の出現率を有症率あるいは有所見率とし た。これら異常所見は認められるが, 総合的に病的状 態には至っていないと判断される群をdisorder, 有症 者 (異常者) とし, その出現頻度を異常者率とし, こ れら異常所見を組合せて, 病的状態と判断した群を Meador のいう non disease, 有病者とした。さらに, これら異常所見から, 臨床診断上特定の疾病と診断さ 
図22 健康水準を表現するための術語の概念

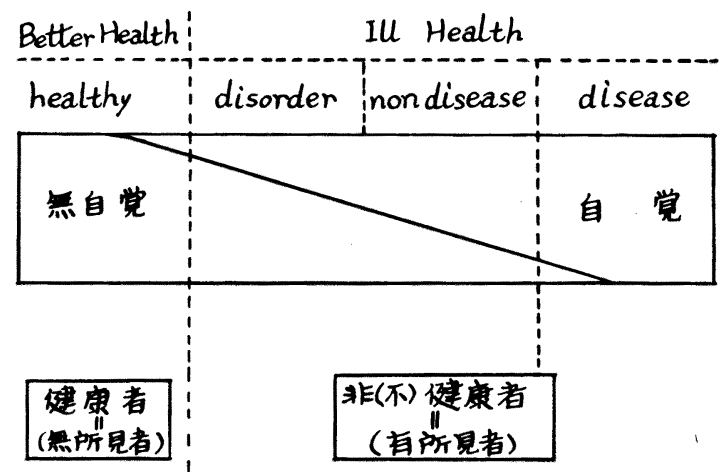

直症者

\section{有病者}

(1) 果常左乙

(2)大Lた所見なし

\section{3)日常生活上要注意}

\section{(4)要精查·要経過㮩察}

\section{(5)要治療}

れるものを disease, 病者, その出現頻度を有病率と して表した。著者らが 5 段階に分類した健康水準の区 分をこれにあてはめると，(1)および (2)は健康者群に属 し, (3)は農夫症や体格・体力の著しい偏りを認めるも のがこれに属し, かかる意味において heal thy と disorder 群の一部を含み, 両者の境界にまたがるボーダーライ ン層として位置づけることができる。また。(4)および (5)は有病者として一括して取り扱ったが, 実質的には, その所見の内容や程度に応じて有症者, 有病者, 病者 それぞれの範嘭に属すべきものである。(4)に分類され たものは，既述のごとく有症者層として位置づけるこ とのできるものが大部分で，(5) は有病者ないし病者と して取り扱うことが妥当なものである。もとより，こ れらの概念は所見のもつ質的内容, 程度の差を的確に 表現するにはなおきわめてあいまいであることを認め ざるを得ない。詳細については別に論じたい。

まず，小地域集団の農業従事者について知り得た健 康水準を個々の生活要因との関連において検討した。 すなわち, 同一世帯の世帯主と主婦についてみると, 主婦では有病者率が高く, 健康者率が低く, その健康 水準に有意の格差が存在した。両者の疾病構造には明 瞭な差異が認められ, 世帯主では循環器系疾患, 主婦 では筫血症が大きな比重を占めている。従って, 両者 にみられる健康水準の差異は季節的に若干異なった様
相を呈し，夏季の農繁期直後の格差がより明瞭である。 こうした両者の格差は, 二種兼業の健康者率の差異に も示されているが, 同時に, 農業経営様態のなかで, 特に 1 ha. 以上の層で煙草耕作，蘭業のごとく労働集 約性の高い傾向にある品目, 逆に, 果樹, 酪農のごと く労働集約性は相対的に低い傾向にある品目，それぞ れに比較的明瞭に認められた。このことは，労働負担 の程度，高い土地生産性を持つ地域における両者の生 活負担の程度を推察するうえで示唆に富む所見と思わ れる。

すでに触れたごとき疾病構造の差異は, 一面, 加令 と共に男子の健康水準を一元的に，しかも著しく低下 せしめ，女子では必ずしも同様の傾向をとらないとい った現象を表わしている。もっとも，60才以後の両者 の疾病構造の様態については, 今後さらに検討しなけ ればならない重要な課題である。

ちなみに，必ずしも同一世帯ではないが，同一地域 の世帯主と主婦との健康者率の相関性は, $\gamma=0.39$ と 中等度の正の相関を示している。しかし，倉岳（主婦 は著しく劣り，世帯主は比較的高水準）や北部（主婦 は比較的高水準，世帯主は相対的に劣る) のごとく, 必ずしも両者が同様の傾向を示さない地域もあり, 今 後の地域研究のきわめて興味ある課題と思われる。

なお，健康水準の季節的推移については，すでに触 れたごとく，夏季の低下傾向は主婦に著しく，冬季の 上昇傾向は世帯主に著しい傾向にあるが，その詳細な 検討は別に報告したい。

都市に居住する家庭の主婦にくらべて農家の主婦の 健康水準が相対的に低いという事実を踏まえて，農業 経営の様態による相違をみると, $0.3 \mathrm{ha}$. 未満の二種兼 業, 農外労働依存度の高い層は相対的に低い。また, 複合経営の形態としては，すでに触れたごとく，蘭業 に低く，果樹に高い。こうした農業経営の様態と健康 水準との関連性は主婦よりもむしろ世帯主に明瞭であ る。現今，主婦農業のあり方が大きな論議を呼んでい るが, 著者らの調査のごとく, 主として専業, 中堅農 家層を対象として取り上げたとき，主婦は非常に低い 水準で比較的均一化の傾向をみせているのに対して, 世帯主では諸種の要因による変動が相対的に大きいこ とを示唆している。

さて, 熊本県の健康水準を県のレベルでみると, 周 産期死亡率や乳児死亡率の改善の立ち遅れ, 依然とし て高い結核死亡率, 感染性疾患による死亡の相対的比 重の高さなどなど全国的にも最も低いレベルに近いと いわざるを得ない。本研究の主題は, 熊本県というマ クロな観点から健康水準を論じることでは必ずしもな 
いので, 詳細は別に譲る。

すでに触れたごとく，農協単位という比較的小さい 機能的地域集団をとった場合, 熊本県の地域でも相当 大きな地域格差が認められる。そこで，その地域性を 少しく整理して健康水準の地域的な分布を, 主婦の健 康者率を指標に検討を加えた。

まず，農林省統計による農業地域，経済地帯別の健 康水準は表 7 のごとくで, 本研究で対象数の少ない山 村を一応除外して検討すると, 農業地域別には県北,

表 7 農業地域・経済地帯別健康者率

\begin{tabular}{|c|c|c|c|c|c|}
\hline 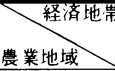 & 都市近郊 & 平地農村 & 農山村 & 山 村 & 計 \\
\hline 県 北 & $13.0 \%$ & 19.5 & 18.1 & - & 19.0 \\
\hline 阿 蘇 & - & 18.2 & 4.0 & $(21.0)$ & 15.9 \\
\hline 県 南 & 14.0 & 9.5 & 11.4 & - & 10.3 \\
\hline 天 草 & - & - & 9.0 & - & 9.0 \\
\hline 計 & 13.5 & 18.6 & 11.3 & $(21.0)$ & 16.5 \\
\hline
\end{tabular}

阿蘇，県南，天草と明瞭な格差が認められ，経済地帯 別には平地農村が相対的に高く，農山村が低い。乳児 死亡率その他の衛生統計指標でみた場合，柳沢らの指 摘のごとく, 都市近郊が最も高く, 山村に低い傾向が みられるが，農業従事者の集団検診の成績を指標にと れば，すでに触れたごとき近年の農村構造，農業生産 条件の変動などもあって，必ずしも同様の傾向を示さ ない。特に, 県南における平地農村の低水準, 県北農 山村の相対的な高水準および都市近郊農村の相対的な 低水準が注目される。そこで，熊本県が，自然条件， 経営条件, 地域類型, 生活圈を総合的に検討して独自 に立案した農業地域および経済地帯区分に従って，上 述の農業地域，経済地帯別にみられた健康水準の分布 格差をより詳細に検討すれば, 図 23 のごとくである。 すなわち, 熊本平野が健康者率 $26.3 \%$ と最も高く, 阿 蘇南部 $(24.0 \%)$, 金峰山簏 $(23.0 \%)$, 菊池南部 (21.0 $\%)$ ，阿蘇中部 $(20.5 \%)$ がこれに次ぐ。逆に，天草上 島が $8.6 \%$ と最も低く,下島北部 $(8.7 \%)$, 八代 $(10.3$ $\%)$, 下球磨 $(10.6 \%)$, 下島南部 $(11.0 \%)$ なども低 い。すなわち，県南は天草，球磨，八代など全般的に 低水準で，なかでも，平地農村としての八代藺業地域 の低水準が注目される。県北では，熊本平野，金峰山 麓, 阿蘇，菊池の相対的な高水準が注目される。観点 を農業経営様態に移して，その内容から地域分布にみ られる格差を検討すると，表 8 のごとくである。すな わち, 昭和 52 年を目途とした農業経営類型別の地域分 布を指標にとれば, 南部および海岸島嶼地域の藺草, 煙草耕作地帯の低水準，中央および高原地域の稲作，
図23農業地域・経済地帯別健康者率

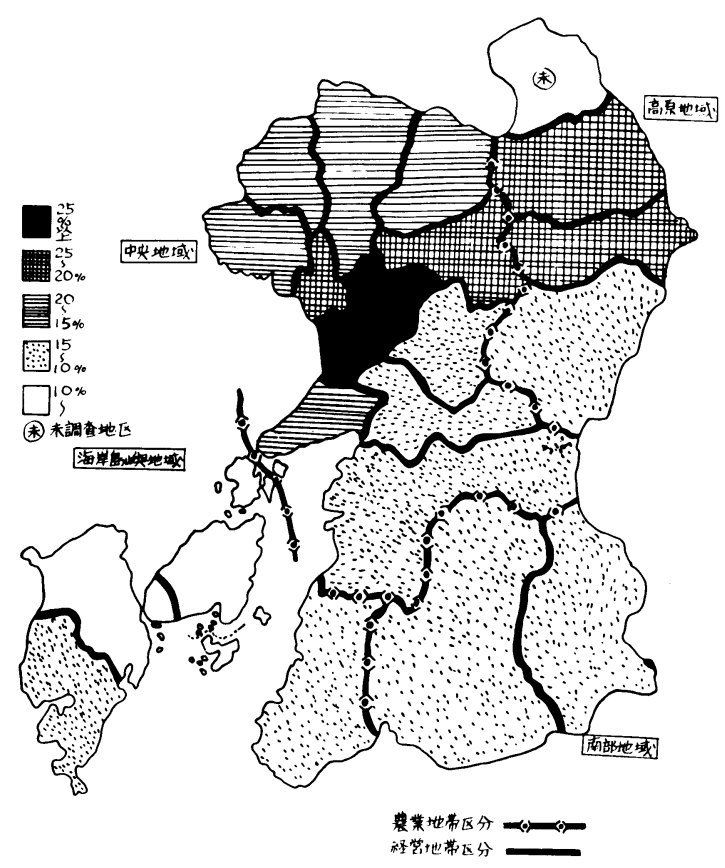

表 8 農業地帯区分・主要経営類型別健康者率

\begin{tabular}{|c|c|c|}
\hline 地带区分 & 主要経営類型 & 健康者率 \\
\hline \multirow{6}{*}{ 中央地域 } & 野莱+稻 & $19.3 \square$ \\
\hline & い草十稲 & $13.9 \square$ \\
\hline & 温州みか人 & $19.7 \square$ \\
\hline & 酪農 & $19.0 \square$ \\
\hline & 野菜 & $14.3 \square$ \\
\hline & い草 & 10.3 \\
\hline \multirow{3}{*}{ 高原地域 } & 稻 & $20.5 \square$ \\
\hline & 野菜十肉用牛十榴 & $24.0 \square$ \\
\hline & 肉用牛+稻 & $13.8 \square$ \\
\hline 南部地域 & たばこ十稻 & $11.0 \square$ \\
\hline \multirow{4}{*}{ 海岸息胞 } & 甘夏みかん & $13.2 \square$ \\
\hline & たばこ十移 & $8.0 \square$ \\
\hline & 温州汃儿 & \\
\hline & 温州加加＋稻 & $11.0 \square$ \\
\hline
\end{tabular}


温州みかん, 酪農地帯の高水準が前述の地域格差に対 応するものである。そこで，分析をさらに一歩進めて，
表 9 のごとく, 地域別の農家一戸当たり生産農業所得, 耕地 10 a. 当たり生産農業所得, 農業専従者 1 人当たり

表 9 地域別土地生産力 - 労働生産力と健康者率との関係

\begin{tabular}{|c|c|c|c|c|c|c|c|c|c|c|c|c|}
\hline 1) & 2万凡丰荡 & $2 \sim 3$ & $3 \sim 4$ & $4 \sim 5$ & $5 \sim 6$ & $6 \sim 7$ & $7 \sim 8$ & $8 \sim 9$ & $9 \sim 10$ & $10 \sim 11$ & $11 \sim 12$ & 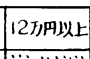 \\
\hline 47万मू2L & & & & & & & & & & ind nn & & अи \\
\hline $45 \sim 47$ & & & & & & & & & & & & \\
\hline $43 \sim 45$ & & & & & & & & & & & & \\
\hline 41,43 & & & & & & 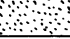 & & & & & & \\
\hline $39 \sim 41$ & & & & & & & 9 & 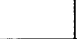 & & & & \\
\hline $37 \sim 39$ & & & & & & 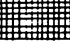 & & & & & & \\
\hline $35-37$ & & & & & & & $\||||| \mid$ & . & & & & \\
\hline $3.3 \sim 35$ & & & & & IIII & & & & & & & \\
\hline $31 \sim 33$ & & & & & $n$ & & & & & & & \\
\hline $29 \sim 31$ & & & & & & InIm & & & & & & \\
\hline $27 \sim 29$ & & & & 㴔 & & & & & & & & \\
\hline $25 \sim 27$ & & & & & & & & & & & & \\
\hline $23 \sim 25$ & & 层 & 3 & 5 & i & & & & & & & \\
\hline $21 \sim 23$ & & 華 & 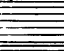 & & & & & & & & & \\
\hline $19-21$ & 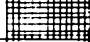 & |linin & 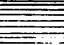 & 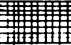 & & & & & & & & \\
\hline $17 \sim 19$ & & w & 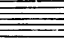 & & & & & & & & & \\
\hline $15 \sim 17$ & & & 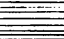 & & & & & & & & & \\
\hline 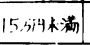 & & & & & & & & & & & & \\
\hline
\end{tabular}

生産農業所得と健康水準との関連を検討した。相互の 相関係数は，それぞれ，0.03，一0.07，0.02で相関は ない。すなわち, 地域の健康水準はその地域の土地生 産性, 労働生産性とは一元的に相関しないことを示し ている。熊本県の農業生産構造が生産性の向上を目途 として大きな転換をとげ始めた昭和 35 年に対する 42 年の土地生産性の比率, すなわち, 土地生産性伸張率 と健康者率とを対比すれば, 図 24 のごとくで, 土地生 産性の著しく伸張した地域と伸びの著しく悪い地域の 健康水準が共に劣るという一定の傾向が認められた。

図24地区別土地生産性伸張率及び健康者率

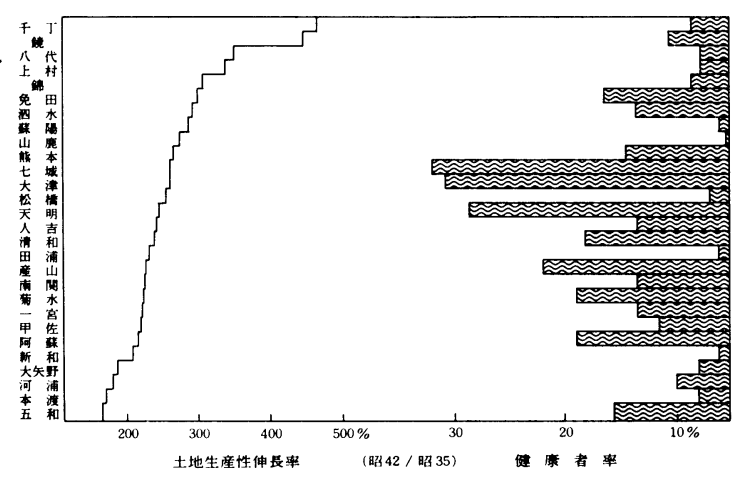

すなわち, 現在の農業生産構造の中に健康を阻害する 要因のあることを示唆するものである。

次に視点を移して，表10のごとき評点方法によって， 地域の総合生活指標の水準と健康水準とを対比すれば, 表 11 のごとくである。なお, 地域の規模は, この場合, 普及所という行政単位でやや広域化しているので, 健 康水準も行政単位にならして検討した。ただし,この 場合の総合生活指標の算定方式については, 指標の選 択や算定方法などになお疑問なしとしないが, 地域的 な生活水準の一応の目安にはなり得ると考える。また, 行政サイドの要請によって行なわれた生活指標策定作 業の成績を地域の健康水準と対比して検討することは, 地域保健を推進する立場からも意味のあることである。

さて, 両者の対応関係は, 人的資源度との相関係数 0.44 , 精神的安らぎ度と 0.48 , 居住条件充実度と 0.49 , 生活水準度と 0.62 , 農業集的度と 0.49 , 市町村勢自立 度と 0.32 , 生活指標合計と 0.47 , 地域水準と 0.47 と かなり高い正の相関関係を示した。農業生産構造の場 合と異なり, 生活構造の地域的なレベルは, 全般的に 地域の健康水準と強い関連性を持っていること, しか も両者の関係はかなり一元的であることを示唆するも のである。

最後に, 市町村別の衛生統計資料による健康指標と 
表10 生活総合指標得点方式算出因子配列表(市町村統計による)

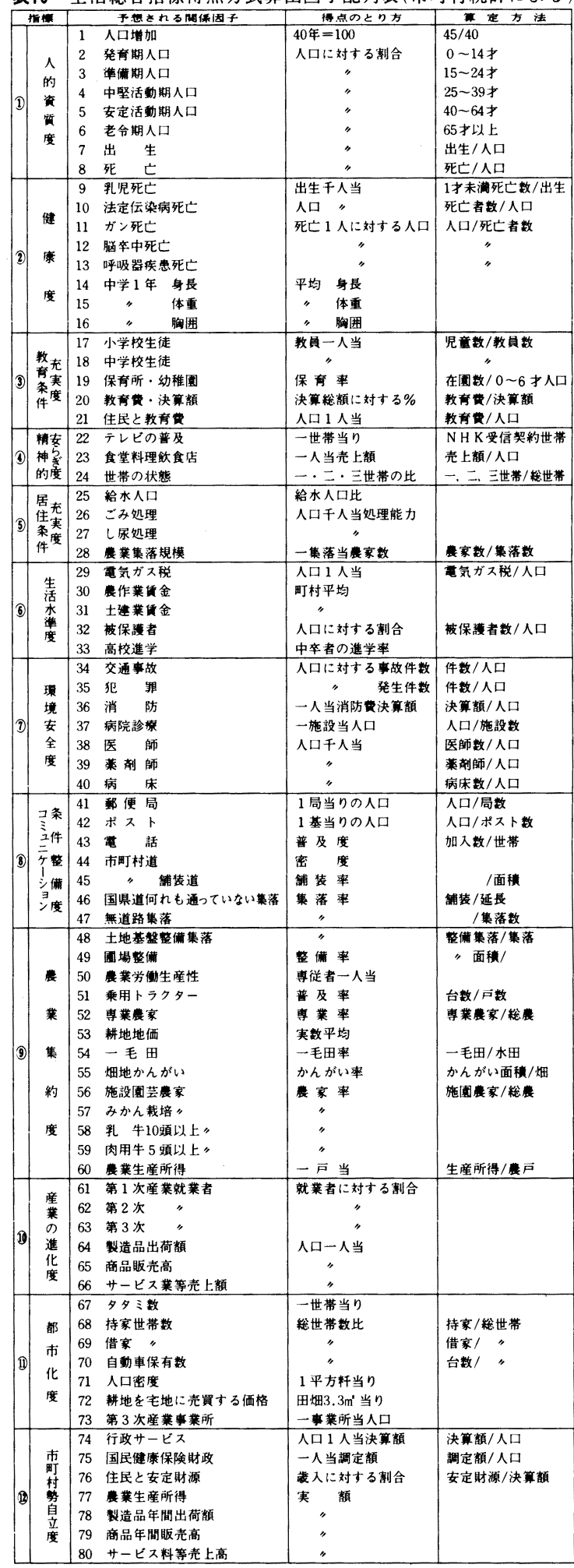

農業従事者の集団検診による有病者率とを対比して検 討した。この場合，医療社会資源の状況が異なる市部 は除外した。両者の相関性は表 12 のごとくで，著者ら が知り得た地域的な健康指標とは全般的に何らの関連 性も見出すことができなかった。僅かに，医師当人口 との間に -0.24 の低位の負の相関を示したのみであり, 地域における医療社会資源の慢性疾患管理における重 要性を示唆するものといえよう。ちなみに, 健康指標 と集団検診成績との関連性を乳児死亡率と中枢神経血 管損傷による死亡率について検討すれば，表 13，14の ごとくである。すなわち，単一の指標の単年としての 数値の変動など, 健康指標のとり方自体にも若干の問 題があると思われるが，いずれにしても，こうした小 地域集団の総合的な健康指標として如何なるものが最 も妥当であるか，もしそれがない場合，いくつかの指 標の組合せを如何なる重みづけをしながら総合的に検 討していくかなど，今後さらに検討を要する課題だと 思われる。

いずれにしても，農業従事者の集団検診成績からみ た地域の健康水準を規定する要因として, 地域生活水 準のレベルおよび農業生産構造の重要性を指摘したい。

本研究は比較的偏りのない, すなわち, 意図的に抽 出された対象については $100 \%$ 近い受診をみた地域の 健康者集団を対象とする cross-sectional survey とし て位置づけられる。そして，一定のスクリーニングレ ベルによる健康水準の策定を通して，慢性疾患を中心 とする状況把握と基本的な生活要因の断面的な解析は 可能であった。かかる意味における地域の健康像, 疾 病像の推移は概ね把握し得たのではないかと考える。 しかし, 本研究のなかでは, 宿主要因の検討が不充分 であるし，また，環境条件のなかでも，野瀬らが追求 している河川や土壊の性質などの物理学的, 生態学的 な検討も別の機会に諼りたい。

いずれにしても，本研究は南九州における地域的健 康疫学調査の一つの試みとして, 今後の prospective surveyの出発点にはなり得ると考える。著者らは, さ らに, スクリーニングレベルの構成を緻密にし, 健康 に関する情報収集の方法を検討すると共に，これらの 情報を多変量解析などの方法を用いてさらに検討を深 め, 何よりも地域保健の実践に当って有用な基礎資料 にしたいと考える。

なお，すでに触れたごとく，本論文で機械的に分類 した健康水準の区分のあいまいさに触れておきたい。 すなわち, 同一の水準にランクされたものでも，いく つかの異常所見が並列的に取り扱われている。すなわ ち, 血色素量 $11 \mathrm{~g} / \mathrm{d} \ell$ 末満のものも鉤虫卵陽性のものも, 
表11 地域別生活総合指標と健康水準の関係

\begin{tabular}{|c|c|c|c|c|c|c|c|c|c|c|c|c|c|c|c|}
\hline & $\begin{array}{l}\text { 人 } \\
\text { 的 } \\
\text { 資 } \\
\text { 源 } \\
\text { 度 }\end{array}$ & $\begin{array}{l}\text { 条教 } \\
\text { 件 } \\
\text { 充育 } \\
\text { 実 } \\
\text { 度 }\end{array}$ & $\begin{array}{l}\text { 安精 } \\
\text { ら神 } \\
\text { ぎ } \\
\text { 度 }\end{array}$ & $\begin{array}{l}\text { 居 } \\
\text { 充住 } \\
\text { 実条 } \\
\text { 度 }\end{array}$ & $\begin{array}{l}\text { 環 } \\
\text { 境 } \\
\text { 食 } \\
\text { 度 }\end{array}$ & $\begin{array}{l}\text { 健 } \\
\text { 康 } \\
\text { 度 }\end{array}$ & $\begin{array}{l}\text { 生 } \\
\text { 活 } \\
\text { 水 } \\
\text { 準 } \\
\text { 度 }\end{array}$ & $\begin{array}{l}\text { 条冭 } \\
\text { 件 } \\
\text { 整 } \\
\text { 備 } \\
\text { 妾寻 }\end{array}$ & $\begin{array}{l}\text { 産 } \\
\text { 業 } \\
\text { 㕠 } \\
\text { 度 }\end{array}$ & $\begin{array}{l}\text { 農 } \\
\text { 業 } \\
\text { 集 } \\
\text { 約 } \\
\text { 度 }\end{array}$ & $\begin{array}{l}\text { 都 } \\
\text { 市 } \\
\text { 化 } \\
\text { 度 }\end{array}$ & $\begin{array}{l}\text { 市 } \\
\text { 自町 } \\
\text { 立森 } \\
\text { 勢 }\end{array}$ & $\begin{array}{l}\text { 指 } \\
\text { 標 } \\
\text { 合 } \\
\text { 計 }\end{array}$ & $\begin{array}{l}\text { 地 } \\
\text { 域 } \\
\text { 水 } \\
\text { 準 }\end{array}$ & $\begin{array}{l}\text { 健 } \\
\text { 康 } \\
\text { 者 } \\
\text { 率 }\end{array}$ \\
\hline 飽 & .08 & 40 & 51.82 & 62.15 & .82 & 63.79 & 62.12 & .83 & .28 & .26 & 69.79 & 72.30 & & 1. & 26.2 \\
\hline 城 & 50.08 & .12 & 50.10 & 52.25 & 50.01 & 53.33 & 52.86 & 51.46 & 50.94 & 51.93 & 48.00 & 54.11 & 3.19 & 1 . & 15.5 \\
\hline 名 & .20 & .37 & 50.60 & 1.24 & .22 & 49.32 & 51.92 & .11 & 51.73 & 52.24 & 50.12 & 55.32 & 19.39 & 1 . & 19.3 \\
\hline 関 & 47.53 & 49.26 & 46.06 & 43.02 & 47.98 & 43.49 & 50.97 & 47.53 & 47.00 & 49.38 & 38.14 & 41.49 & & 6 & 14.7 \\
\hline 本 & 50.62 & 48.84 & 51.94 & 48.20 & 50.41 & 50.17 & 52.62 & $48.7 i$ & 49.04 & 53.14 & 47.64 & 51.87 & & 50. & 18.2 \\
\hline 池 & .23 & .72 & 53.06 & .45 & .65 & 51.29 & 52.65 & 48.14 & 49.14 & 55.51 & 48.00 & 49.82 & 616.66 & 1. & 16.8 \\
\hline 津 & 51.95 & .09 & 50.78 & 7.76 & .02 & 47.24 & 60.75 & 0.30 & 49.11 & 58.70 & 47.45 & 45.64 & & & 34.0 \\
\hline 蘇 & 47.58 & 47.84 & 50.82 & 50.93 & 45.73 & 57.76 & 55.64 & 50.68 & 46.98 & 50.10 & 49.50 & 52.62 & 606.18 & 50. & 15.3 \\
\hline 小 & .21 & 45.79 & 52.98 & 50.30 & 47.20 & 49.43 & 52.26 & 51.68 & 49.57 & 41.84 & 53.59 & 51.64 & & 49. & 17.2 \\
\hline 南 阿 蘇 & 50.62 & .61 & 49.00 & 50.99 & .65 & 50.23 & 46.79 & 49.86 & 45.17 & 48.50 & 43.76 & 46.49 & & & 24.0 \\
\hline 陽 & 48.32 & 40.12 & 42.70 & 48.71 & 46.55 & 52.63 & 46.65 & 53.05 & 44.29 & 47.56 & 43.91 & 44.37 & & 46. & 4.0 \\
\hline 上益 城 & 52.85 & 47.34 & 47.22 & 5.57 & 49.41 & 50.91 & 52.50 & 51.19 & 47.55 & 50.70 & 45.56 & 46.06 & 586.86 & 48. & 14.3 \\
\hline 部 & & 48.49 & & & 41.40 & 46.49 & 47.90 & 47.58 & 45.69 & 48.70 & 42.63 & 46.37 & & & 18.7 \\
\hline 代 & 59.06 & 70.11 & 53.02 & 47.20 & 50.21 & 56.51 & 59.23 & 51.21 & 60.20 & 57.53 & 54.23 & 58.05 & & & \\
\hline 鏡 & 52.43 & 52.77 & 46.24 & 44.38 & 45.69 & 48.86 & 51.52 & 48.44 & 51.77 & 57.27 & 49.87 & 49.16 & 598.84 & 49.90 & 9.5 \\
\hline & & 47.78 & 49.98 & 9.86 & 52.09 & 54.25 & 46.66 & 49.92 & 55.02 & 48.61 & 50.08 & 51.71 & & 50. & 13 \\
\hline & 52.47 & 47.98 & 50.14 & 45.20 & 53.68 & 47.65 & 45.50 & 43.15 & 50.22 & 46.43 & 51.78 & & & & \\
\hline 上球 磨 & 50.44 & 57.18 & 47.28 & 47.41 & 40.61 & 50.16 & 50.02 & 47.00 & 49.61 & 47.11 & 46.47 & 50.79 & 592.08 & 49.34 & 10.3 \\
\hline 天草中央 & 50.58 & 47.11 & 51.40 & 47.48 & 55.56 & 43.14 & 40.73 & 50.54 & 51.09 & 47.47 & 51.14 & 47.82 & 584.05 & 48.67 & 11.0 \\
\hline & 45.83 & 47.57 & 54.88 & 51.17 & 44.20 & 43.09 & 42.07 & 46.44 & 49.93 & 46.17 & 48.27 & 46.32 & 565.94 & 47.16 & 16.0 \\
\hline 岳 & 40.67 & 48.88 & 44.69 & 49.90 & 47.97 & 45.96 & 39.42 & 50.89 & 46.74 & 47.38 & 43.36 & 44.13 & 548.99 & 45.75 & 3.8 \\
\hline 南 & 114.08 & 47.74 & 51.42 & 54.76 & 52.56 & 44.06 & 40.92 & 47.91 & 46.32 & 46.03 & 48.72 & 45.93 & 570.45 & 47.53 & 7.5 \\
\hline 相関係数 & 0.44 & 0.12 & 0.48 & 0.49 & 0.13 & 0.22 & 0.62 & 0.15 & 0.26 & 0.49 & 0.27 & $0.32 \mid$ & $0.47]$ & 0.47 & \\
\hline
\end{tabular}

表12地域における健康指標と有病者率との関係（郡部のみ）

\begin{tabular}{|c|c|c|c|c|c|c|c|c|c|c|}
\hline 指標 & 相死亡率 & 乳児死亡率 & $\alpha$-index & 未熟児率 & 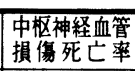 & 伝染病届出率 & 水道普及率 & 医師当人口 & 1 人当解生費 & 従属人口指数 \\
\hline 米保数 & -0.11 & -0.10 & 0.08 & -0.19 & -0.02 & 0.06 & -0.03 & -0.24 & 0.15 & -0.16 \\
\hline
\end{tabular}

収縮期血圧が $180 \mathrm{mmHg}$. のものも同様に (5) として取り 扱われているがごときである。ここに，単一疾患（所 見)の縦の系列的な処理と, 複数疾患 (所見) の横の
系列的な処理, 両者を総合するに当っての困難さがあ る。著者らは,これらの資料をもとに, 疾病構造によ る考察, 疾病や異常所見の相互の関連性を検討し，そ 
表13 地域別乳児死亡率と有病者率の対応

\begin{tabular}{|c|c|c|c|c|}
\hline 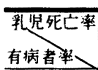 & 19未満 & $20 \sim 29$ & $30 \sim 39$ & $40 \sim 49$ \\
\hline 40未満 & & 大津. 津奈木. & 天明. & 菊水. 七城. \\
\hline $40 \sim 54$ & 天水. & $\begin{array}{l}\text { 河内. 嘉島. } \\
\text { 小川. 砥用. } \\
\text { 相良. 不知火. } \\
\text { 倉岳. 矢部. }\end{array}$ & $\begin{array}{l}\text { 一宮. 阿蘇. } \\
\text { 御船. 河浦. }\end{array}$ & 白水. \\
\hline $55 \sim 69$ & 産山. & $\begin{array}{l}\text { 南関. 植木. } \\
\text { 甲佐. 清和. } \\
\text { 田浦. 三角. } \\
\text { 松島. 五和. }\end{array}$ & $\begin{array}{l}\text { 鹿本. 千丁. } \\
\text { 湯浦. 錦. }\end{array}$ & 北部. 旭志. \\
\hline 70以上 & & $\begin{array}{l}\text { 泗水. 松橋. } \\
\text { 鏡. 上. 免田. } \\
\text { 新和. }\end{array}$ & $\begin{array}{l}\text { 合志. 蘇陽. } \\
\text { 大矢野. }\end{array}$ & \\
\hline
\end{tabular}

表14 地域別中枢神経血管損傷死亡率と有病者率の対応

\begin{tabular}{|c|c|c|c|c|}
\hline 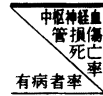 & 15未満 & $15 \sim 29$ & $30 \sim 44$ & 45 以上 \\
\hline 40未満 & & $\begin{array}{l}\text { 天明. 菊水. } \\
\text { 七城. 津奈木. }\end{array}$ & 大津. & \\
\hline $40 \sim 54$ & 倉岳. & $\begin{array}{l}\text { 河内. 天水. } \\
\text { 白水. 嘉島. } \\
\text { 相良. 不知火. } \\
\text { 河浦. }\end{array}$ & $\begin{array}{l}\text { 一宮. 小川. } \\
\text { 砥用. }\end{array}$ & $\begin{array}{l}\text { 阿蘇. 御船. } \\
\text { 矢部. }\end{array}$ \\
\hline $55 \sim 69$ & 産山. & $\begin{array}{l}\text { 北部. 鹿北. } \\
\text { 旭志. 清和. } \\
\text { 千丁. 田浦. } \\
\text { 湯浦. 錦. 松 } \\
\text { 島. }\end{array}$ & $\begin{array}{l}\text { 南関. 鹿本. } \\
\text { 甲佐. 三角. } \\
\text { 五和. }\end{array}$ & 植木. \\
\hline 70 以上 & & $\begin{array}{l}\text { 合志. 泗水. } \\
\text { 蘇陽. 上. 免 } \\
\text { 田. 新和. }\end{array}$ & 松橋. & 鏡. 大矢野. \\
\hline
\end{tabular}

の成績を別に報告したいと考える。さらに，ここで著 者らの得た資料を基礎に, 今後, 長期間に亘る追跡, 観察を通して初めて, 個々の所見についての正当な評 価が可能になり，ひいては，このような多項目スクリー ニングの際の総合的な判定方法や個々の所見の重みづ けも可能になるのではないかと考える。

\section{5. 結語}

（1）熊本県下の 67 地区の農業従事者のうち，20 およ り 59 才までの自らは健康だとして日常作業に従事して
いる6,597 名（1地域 100 名を層別抽出。受診率 98.5 \%)について健康調査を実施した。

（2）健康調査の内容は, 各種の衛生統計から, 農村 に高頻度に存在すると推定された慢性疾患の一次スク リーニングとして設計した。健康診断の成績に基いて, 健康管理対策を推進する立場から, 個人別に 5 段階の 健康水準を設定した。

（3） 67 地域の健康調査成績を概括すれば，男子の健 康者率は $28.3 \%$, 有病者率は $50.0 \%$, 女子の健康者 率は $16.5 \%$ （熊本市， $47.4 \%$ ）と全般的に低水準で, 特に女子の都市部との格差が注目された。

(4) 同一世帯の主婦は世帯主に比し, 明らかに健康 水準が低位であった。この傾向は, 季節的に, 夏季に 著明であった。なお, 男子と女子とでは疾病構造に顕 著な差異が認められた。

（5）年令的には, 男子は加令と共に一元的な健康水 準の低下が認められ, 女子は 20 才および 50 才代前半 で低位を示したが, 男子にみられた一相性の変動とは 様相を異にするものであった。

(6) 熊本県という100万単位の地域集団の枠内にお いても, 健康水準の地域差は顕著なものであった。す なわち, 県北, 阿蘇地方は県南, 球磨, 天草地方より も明らかに優位を示した。一般的な地域差の要因とし て, 社会的な地理条件としての地域生活水準および農 業生産構造の重要性が指摘された。

(7) 農業経営の様態と対比すれば, 二種兼業の零細 農家で, 農外労動への依存度の高い層の水準が劣って いた。他方, 藺草および煙草耕作との複合経営形態を とる層もまた低く, 果樹農家層に高い傾向が認められ, 地域的な農業生産性のレベルとは矛盾する傾向を示し, 注目された。

（8）本研究は，抽出された対象の $98.5 \%$ の受診率を 得た, 地域の「自立経営, 中堅農家層」を中心とした 健康者集団を対象とする断面的な健康水準把握の試み である。かかる意味において, 男子は女子に比し比較 的優位を示したが, 階層別の変動は女子よりもむしろ 大きく，女子は全般的にきわめて低水準であり，地域 的格差は男子よりもむしろ明瞭に認められることは注 目すべき所見と思われた。

(9) 本研究は, 今後の農村の変貌の中での Prospective Surveyの基礎資料として，さらにスクリーニングの構 成を緻密にし，健康に関する情報の収集をさらに考虑 しつつ活用したいと考える。

稿を終えるに当たり，本研究に多大の御協力，御援助を頂い た熊本県農業協同組合中央会, 関係農業協同組合, 熊本県農協 
婦人部連絡協議会を始め, 熊本県衛生部, 熊本県農政部の関係 各位ならびに熊本農村医学研究会の会員諸氏に対し，厚くお礼 を申し上げます。

なお，本論文の要旨は昭和 47 年 10 月，石川県七尾市におけ る第 21 回日本農村医学会総会において発表した。

\section{文献}

1) Wilson J.M.G.et al.: 疾病スクリーニングの原理と実際, W.H.O Public Health Papers, 34, 1970.

2）宮坂忠夫他：地区診断の理論と実際, 績文堂, 昭 34 .

3）野村 茂：九州地方農村, 農村保健, 医学書院, 352 357, 1969.

4) 近藤康男：農村保健の背景, 農村保健, 医学書院, 18 47, 1969.

5）飯塚鉄雄他：日本人の体力標準值, 東京都立大学身体適性学 研究室編, 不味堂, 1970.

6）等 泰三：農村婦人の資血に関する研究，久留米医会誌，33 (2), 1970.

7) Takamatsu, M.et al.: Studies on labour conditions and health hazards of rush (igusa) harvesting process, IV th International Cougress of Rural Medicine ibid., Abstract, 54, 1969.

8）二塚 信他：複合経営の健康にもたらす諸問題，第11回社会
医学研究会講演概要集, 1970.

9）柳沢文徳：地域類型と健康水準の関連，看護技術，16(10), 1970.

10）科学技術庁資源調査会：農村における保健福祉の向上と生活 環境の改善に関する基礎的報告, 科学技術庁資源調査会報告 第 20 号, 1961.

11) 重松逸造: 健康の疫学, 公衆衛生, 22( 5 ), 1958.

12) Meador, C.K.: The art and Science of nondisease, New. Eng. J.Med., 272, 92, 1965.

13）二塚 信他：農村婦人における筫血の季節的推移, 日本公衛 誌, 18(10), 1971.

14）二塚 信：熊本県の健康水準，熊本日日新聞連載資料, 1971.

15）柳沢文徳他：経済地帯別（農林省）にみた健康水準に関する 解析, 厚生の指標, 14(15), 1967.

16）熊本県農政部: 農業地帯および経営地帯の設定, 熊本県地域 農業計画資料, 1972 .

17）熊本県農政部：総合生活指標による農村地域の生活水準の測 定 (未定稿), 1972.

18）重松冕造：疫学序説，公衆衛生，32(3)，1968.

19）野瀬善勝他：脳卒中並びに胃ガン死亡率の土地集積性に関す る調査研究, 年報, 山口産業医学, 17号, 1970.

20）芦沢正見：慢性疾患に関する集団の疫学的調査の意義，循環 器疾患, 16 41, 1969.

\title{
On the Living Conditions and Health Level in Communities
}

\author{
Makoto Futatsuka, Yoshiki Arimatsu, Atsushi Ueda, \\ Junichi Misumi, Tadako Ueda, Junichiro Kawasaki, \\ Wasaku Koyama, Yoshitaka Takekuma, Kazuharu \\ Nagao, Hidenobu Matsukane, Katsuko Ueda, Makoto \\ Takamatsu, Toshio Matsushita, Shigeru Nomura*
}

Nowadays the agricultural production system in the farm area has remarkably been changed and this has influenced the farmers in many aspects of life.

We tried by epidemiologic cross-sectional survey to ascertain the health level of 6,597 farmers, who are self-supporting and middle class in the sixty-seven different districts of Kumamoto Prefecture. It is noticeable that judging from the difference of districts, the health level of the farmers who have a big agricultural production is low, and judging from the difference of the class, that of the farmers who have other jobs besides agriculture is low, too. In general, the health level of males is relatively higher than that of females, but the health level of males is higher than that of females, depending on the class difference.

Generally speaking, we noticed that the health level of female is very low, and at the same time the variation of the health level of females is more remarkable than that of males, depending on the quality of the district in which they live.

These resutls of these investigations should be utilized as the basic materials source for a prospective survey of changing farm village from now.

\footnotetext{
*Kumamoto Rural Medicine Association
} 